\title{
Applications of Local Floras for Floristic Subdivision and Monitoring Vascular Plant Diversity in the Russian Arctic
}

\begin{tabular}{|r|l|}
\hline Journal: & Arctic Science \\
\hline Manuscript ID & AS-2015-0010.R4 \\
\hline Manuscript Type: & Article \\
\hline Date Submitted by the Author: & 21-Jun-2016 \\
\hline Complete List of Authors: & $\begin{array}{l}\text { Khitun, Olga; Komarov Botanical Institute, Far North Vegetation Lab } \\
\text { Koroleva, Tatiana; Komarov Botanical Institute, Far North Vegetation Lab } \\
\text { Chinenko, Svetlana; Komarov Botanical Institute, Far North Vegetation Lab } \\
\text { Petrovsky, Vladislav; Komarov Botanical Institute, Far North Vegetation } \\
\text { Lab } \\
\text { Pospelova, Elena; Taimyrsky Nature Reserve, } \\
\text { Pospelov, Igor; A. N. Severtsov Institute of Ecology and Evolution, } \\
\text { Laboratory for Biodiversity Concervancy and Bioresources Use } \\
\text { Zverev, Andrei; Tomsk State University, Botany Department }\end{array}$ \\
\hline Keyword: & \begin{tabular}{l} 
phytogeography, local flora, database, monitoring, Russian Arctic \\
\hline
\end{tabular} \\
\hline
\end{tabular}


Khitun O.V. ${ }^{1}$, Koroleva T.M. ${ }^{1}$, Chinenko S.V. ${ }^{1}$, Petrovsky V.V. ${ }^{1}$, Pospelova E.B. ${ }^{2}$, Pospelov I.N. ${ }^{3}$, Zverev A.A. ${ }^{4}$

\section{Applications of Local Floras for Floristic Subdivision and Monitoring Vascular Plant Diversity} in the Russian Arctic

${ }^{1}$ Komarov Botanical Institute Russian Academy of Science, Prof. Popov street 2, 197376 St.Petersburg, Russia, e-mail: khitun-olga@yandex.ru

${ }^{2}$ Taimyrsky Nature State Reserve and Moscow State University, parnassia@mail.ru

${ }^{3}$ Taimyrsky Nature State Reserve and A. N. Severtsov Institute of Ecology and Evolution, taimyr@orc.ru

${ }^{4}$ Tomsk State University, ibiss@,rambler.ru

Corresponding author: Olga Khitun 


\begin{abstract}
The local flora method has been used by Russian botanists for studying vast wilderness areas. The method strives to determine the total flora within a certain limited area and provides comparable data for spatial comparisons between different locations and temporal comparisons at the same location. Complete vascular plant diversity was sampled in 240 localities with an area between 100$300 \mathrm{~km}^{2}$ each throughout the Russian Arctic. These data were incorporated in a specially developed Integrated Botanical Information System (IBIS). This database provides a unique opportunity to study spatial gradients of different floristic variables. Pair-wise similarity of species composition and proportions of various phytogeographical groups in local floras were used in a floristic subdivision of the Russian Arctic. The floristic units derived by this method often resembled subprovinces of Yurtsev (1994), but there were also several areas of non-alignment. Application of local floras for monitoring of temporal changes has several constraints. However, nine local floras were re-visited 20-70 years after the initial survey. Increases in the number of Boreal and Hypoarctic species were recorded in the southern local floras. Standardized methods and the use of modern technical tools for accurate documentation could enable use of this approach at observatories across the Arctic.
\end{abstract}

Keywords: phytogeography, local flora, Russian Arctic, database, monitoring 


\section{Introduction}

The global problems of biodiversity conservation as well as the assessment of climatic changes and anthropogenic impacts require both inventory and monitoring of existing diversity (Callaghan et al. 2013; Cramer et al. 2014; Walker et al. 2013). Availability, comparability and quality of data for the study of global patterns in plant diversity are major problems and often require various methods of extrapolation (Kier et al. 2005). Data can be collected using a formal grid approach (Grytnes et al. 1999; Qian 1998) or using administrative or geographical divisions (Qian 1999; Qian et al. 2003). However, the latter approaches may require recalculation of species richness per standard area (Malyshev 1975).

Approaches to analysis of plant species diversity at the landscape and regional levels were developed in Russia for comparative floristic studies based on the 'local flora method' elaborated by Tolmatchev $(1931,1974)$ and his disciples (Rebristaya 1977; Yurtsev 1982, 1987, 1997). This method was suggested for studying vast wilderness areas in northern Russia. The method is based on the concept that detailed information obtained from a limited number of sites provides better knowledge of regional flora than occasional irregular plant sampling. This approach has been widely used by Russian botanists in various bioclimatic zones since the 1960's (Baranova 1994; Bubyreva 1998; Koroleva et al., 2008, 2010, 2011, 2012; Naumenko 2008; Rebristaya 1977, 2013; Sergienko 2013 and many others). Some publications have introduced the local flora concept to western readers (Penev 1997; Balandin 2008; Khitun et al. 2013), but the approach has not been applied in North America except for a single study, which used it for distinguishing four floristic subregions within the Canadian Arctic Archipelago (Talbot et al. 2008).

The aims of this paper are: (1) to provide a short introduction to the local flora method and its application in the Russian Arctic; (2) to show how the network of local floras throughout the Russian Arctic can be used for the assessment of geographical patterns of various floristic parameters and test a 
numerical approach for floristic subdivision; and (3) present the results of the first attempts of biodiversity monitoring at the local flora level.

\section{Materials and methods}

\section{The local flora method}

Tolmatchev (1931) proposed that a minimal natural (in contrast to administrative) floristic entity can be distinguished in nature ('elementary flora') and compared with other such units. Though the theory was debated in Russian literature (Tomatchev 1974; Yurtsev 1975, 1987; Sheljag-Sosonko 1980), in practice, the method strives to determine the total vascular plant flora in a specific locality, therefore it became known as the local flora method (Sheljag-Sosonko 1980). Tolmatchev (1931) did not specify the size of an elementary flora, but mentioned that it should (1) include all the known habitat types present at the locality, and (2) should be homogenous in that the same sets of species occupy certain habitats throughout the area. Empirically it has been shown that the representative area for study could vary between different geographic zones. In the Arctic, the area for study is approximately $100 \mathrm{~km}^{2}$ in lowlands and $300 \mathrm{~km}^{2}$ in mountainous regions, whereas for the taiga zone it is ca. $600 \mathrm{~km}^{2}$ (Tolmatchev 1974; Schmidt 1972; Yurtsev 1987).

Since the 1960's researchers from the Laboratory of the Far North Vegetation at Komarov Botanical Institute, Russian Academy of Sciences have visited almost 500 sites in the Russian Arctic, mainly in its Asian part. In approximately a half of these, more extensive studies determined local floras. A thorough search through the study areas resulted in finding many rare species. Such knowledge is important for understanding ecological and historical determinants of spatial patterns of biodiversity, as well as for biodiversity conservation (Rosenzweig 1995). Part of this information (mainly concerning species distributions and ecology) was included in the 10 volumes of The Arctic Flora of the USSR (1960-1987), later in The Panarctic Flora (Elven 2007) and in Checklist of Flora of the Chukotkan Tundra (Yurtsev et al. 2010). 
Species lists for many local floras were published and analyzed but they were never analyzed all together. Yurtsev (1997) suggested the idea of biodiversity monitoring at the level of local floras. A local floras database was started in the Integrated Botanical Information System (IBIS) created by Zverev (1998, 2007). Local floras were selected for the network according to several criteria (Yurtsev et al. 2001; Balandin 2008): (1) completeness of the species list, which can be estimated by comparing with other local floras from the same subzone in the given region; (2) presence of rare relic species or rare habitats; (3) availability of the annotations of the checklist, including comments on the abundance of each species and indications where rare species were found.

The local floras network and database provides a unique opportunity to study spatial gradients of different floristic variables (Yurtsev et al. 2002, 2004; Koroleva et al. 2008, 2011, 2012 etc). For example, differences were demonstrated between the Yamal-Gydan, Taimyr and Chukotka sectors for several taxonomical features of local floras, such as number of species, genera and families; number of species in the 5 and 10 richest families; and ratios of Asteraceae to Poaceae, and Cyperaceae to Poaceae (Yurtsev et al. 2001, 2002, 2004; Khitun et al. 2013).

\section{Phytogeographical elements and floristic division of the Arctic}

Along with taxonomic diversity, typological diversity of organisms can be assessed (Yurtsev 1999), when considering characteristics other than systematic affinity. For example, taxa can be classified into groups according to the similarity of their geographic distributions phytogeographical elements. Analysis of the geographical structure of local floras, which means analysis of compound and proportions of phytogeographical elements, is an obligatory part of any comparative floristic study (Baranova 1994; Rebristaya 1977, 2013; Naumenko 2008; Sergienko 2013).

Traditionally in Russian Arctic phytogeography, zonal (latitudinal) and longitudinal distributions are considered separately (Tolmatchev 1974; Yurtsev et al. 1979). Although longitudinal distributions of species are usually estimated similarly by different authors, their latitudinal distribution can vary in different sectors of the Arctic and the same species can be placed in different 
groups depending on the region (compare: Matveeva and Zanokha 1997; Rebristaya 1977; Sekretareva 1999; Yurtsev et al. 1979). Therefore, a critical revision of species distributions with a focus on distributions throughout the tundra zone in Russia was completed for this project (Table 1). Species distributions were assessed according to maps in The Arctic Flora of the USSR (1960-1987), Flora of Siberia (1987-1997), Hultén and Fries (1986), Kharkevich (1985-1996), numerous publications in Botanicheskii Zhurnal and unpublished local flora data. We used a two-level system of classifying distribution patterns: subgroups according to similarity in their distribution are joined into groups. Longitudinal groups in this study generally reflect distribution within two continents-Eurasia and North America (Table 1). Each species in the database was assigned to one longitudinal subgroup and, respectively, to one group, and also to one latitudinal subgroup and respective group; therefore there is no overlap in species between geographical subgroups or groups.

[TABLE 1. Description of phytogeographical elements (longitudinal and latitudinal groups and subgroups) in the Russian Arctic flora]

A provincial division of the Arctic (west to east) was suggested by Yurtsev et al. (1978) and somewhat revised in Yurtsev (1994) (Fig.1). It was based on distinguishing the sets of differential (i.e. present only in one subprovince or province) and co-differential (present in two neighboring subprovinces or provinces) species. Along with the terms 'province' and 'subprovince', the word 'sector' is also used as it does not have any phytogeographical rank and can be used for discussing both provinces and subprovinces.

The Kola sector was not included in the Arctic floristic region (Yurtsev 1994), as its status was disputed. Investigations of the Murman coast local floras (Chinenko 2008, 2013) showed their similarities with the East European Arctic local floras and suggested the inclusion of the Murman coast into the Arctic. We consider this territory as the Kola-Karelian subprovince of the European-West Siberian Province. 
Sectoral (provincial and subprovincial) and zonal (north to south) divisions were consciously separated by Yurtsev et al. (1978). In this paper, we follow the Circumpolar Arctic Vegetation Map terminology for subzones (CAVM team 2003) because the boundaries in the Russian portion of the map were drawn in agreement with B. A. Yurtsev, according to the newer data. Hereafter, High Arctic tundra, as it was called in Yurtsev (1994) is referred as subzone A; Northern Arctic tundra - as subzone B; Southern Arctic tundra - subzone C; Northern Hypoarctic tundra - subzone D; and Southern Hypoarctic tundra - subzone E. Restricted to northeasternmost Asia, the stlanik subzone (creeping shrubs Pinus pumila (Pall.) Regel formation) is also included in subzone E. As the southern boundary of the Arctic floristic region is still disputed (Yurtsev 1994, CAVM team 2003), floras from forest-tundra and northern taiga were also included into the network of areas (named subzone F and G, respectively).

Currently, many authors apply numerical approaches to regionalization (Malyshev et al. 2000, Qian et al. 2003). With local flora data, we tested how agglomerative classification based on the cluster analysis of species composition similarity and similarity of longitudinal structure of local floras corresponds with the floristic division suggested by Yurtsev (1994).

\section{Sampling of local floras}

Guidance to study local floras was provided in Tolmatchev (1974). However, locations vary widely so it is difficult to develop a standard set of habitat types that would apply everywhere. Furthermore, there is some discrepancy in understanding and distinguishing various habitat types (compare: Tolmatchev 1932; Pospelova and Pospelov 2001; Khitun 1998; Zanokha 1987). However, it does not influence the final species list as long as all different subdivisions of the landscape are thoroughly inventoried. Ideally, the choice of location would be determined by objective criteria and based on a pre-analysis of available geoecological information (geology, geomorphology, soils and vegetation). In reality, the choice of study locations is often based on proximity to existing infrastructure and logistic considerations. 
In practice, studying a local flora means thoroughly examining the area around a base location by radial routes of about 5-7 km long over 2-3 weeks, compiling species lists of all habitat types that can be distinguished with some replication (at least 5-10 times for common habitats and as many as were found for rare habitats). The skill of a good botanist is the primary limiting factor for the method, but that is the case in any floristic research. Herbarium vouchers are collected for all species and in every case when the determination in the field is in doubt. For each species, information about its distribution within the study area is provided. The work results in an annotated checklist of the local flora. Although comments on species abundance and frequency of occurrence remain subjective (as they are based on coarse visual estimates), the standardized terminology for abundance (solitary, sparse or abundant) and frequency of occurrence (rare, sparse or common), reduces error. However, in the study of spatial gradients of floristic variables only presence/absence data were used.

The required search of all existing habitat types within the study area distinguishes this method from other kinds of surveys and especially from random sampling and sampling along transects at regular intervals. Complete $(100 \%)$ local flora cataloging is probably never achieved after one field season; usually about $90-95 \%$ of a local flora can be determined by an experienced botanist. In many cases, even negative specificity of the flora (at least at the regional level) can be discussed. However, a major deviation in species richness of one local flora from others in the same region may indicate that the locality was not studied well enough, especially if there is no objective reason (for example, different landscape) for the deviation. The fact that at least two botanists specializing in Arctic flora and vegetation were working together at each site, provided a high degree of completeness of the studied local floras.

Currently, 240 local floras from all parts of the Russian Arctic and adjacent forest-tundra and northern taiga are included in the network (Fig. 1). The majority of local floras were studied during the period from 1965 to 2014. The coordination and updating of taxonomy is necessary, as it continuously changes and older species lists require checking before inclusion into the local floras database. Taxonomy in the database follows Arctic Flora of the USSR, however, nomenclature in this paper is 
updated according to Elven (2007). During the last 15 years nine localities were re-visited and inventoried again in the same way as all other local floras.

\section{[FIGURE 1]}

\section{Statistical analysis}

Species composition similarity was calculated pair-wise for 240 local floras using Czekanowski-Dice-Sørensen’s similarity index

$$
K_{A B}=\frac{2 C}{A+B}
$$

where $\mathrm{A}$ is the number of species in local flora $\mathrm{A} ; \mathrm{B}$ is the number of species in flora $\mathrm{B}$ and $\mathrm{C}$ is the number of species common for two local floras.

In the Integrated Botanical Information System (IBIS) the number and proportion of species belonging to various geographical subgroups or groups (Table 1) in each local flora can be counted automatically. IBIS allows matrix counts of pair-wise similarity of the proportion of different subgroups or groups in local floras using the modification of Czekanowski-Dice-Sørensen similarity index - "percentage similarity” (Renkonen 1938; Yurtsev, Semkin 1980), elaborated for comparison of quantitative characters:

$$
K_{A B}^{\prime}=\sum_{i=1}^{n} \min \left(p_{i A}, p_{i B}\right)
$$

where $K_{A B}^{\prime}$ indicates similarity between flora $\mathrm{A}$ and $\mathrm{B}, p_{i A}$ is the proportion of total species in the local flora $\mathrm{A}$ in the phytogeographical group or subgroup $(i), p_{i B}$ is the proportion of total species in the local flora B in the same phytogeographical group or subgroup $(i)$.

Matrices of similarity of both indexes were exported from IBIS to Statsoft Statistica 8.0 (Hill, Lewicki 2007) and hierarchical agglomerative cluster analysis was performed. Different results can be achieved depending on the kind of linkage method used for cluster analysis. Unweighted and Weighted Pair-Group Method Using Arithmetic Averages (UPGMA and WPGMA respectively) are the most frequently used linkage strategies for floristic datasets. We used WPGMA-method, because it 
is preferred when we presuppose clusters of different size (Sneath, Sokal 1973; Malyshev et al. 2000; Zverev 2007).

Local floras belonging to different clusters obtained by similarity of species composition or by similarity of longitudinal groups were indicated on the maps.

\section{Results}

\section{Analysis of similarity of species composition of local floras}

The network of local floras throughout the whole Russian Arctic permits a comparison of a numerical approach to earlier floristic subdivision methods. The results of the cluster analysis of species composition similarity (Fig. 2) were used to create a map of floristic differentiation in the Russian Arctic (Fig. 3). The floristic units derived by this method often resemble the boundaries of Yurtsev (1994), but there are also several areas of non-alignment (compare: dotted lines and colored outlines in Fig. 3). The numeric methods, while presenting a more quantitative approach for the determination of boundaries, rely on almost the same relative scarcity of local floras in many areas of the Russian Arctic that Yurtsev faced, therefore exact position of many boundaries is still unclear. In areas such as Chukotka, there was a high concentration of locations with complete local floras and the computed boundaries align fairly well with those of Yurtsev (1994). The local floras of different subprovinces of Chukotka were clearly divided in the cluster analyses (Fig 2 and 3): the Wrangel Island subprovince (cluster 4D), Beringian Chukotka (cluster 6C), Continental Chukotka (cluster 6B) and Southern Chukotka (cluster 6A).

[Fig. 2. Dendrogram of pair-wise species composition similarity of 240 local floras in the Russian Arctic and Subarctic]

A notable difference between the numerical approach versus Yurtsev's scheme was that the numerical approach showed overlaps between the zonal and sectoral subdivisions. Also, there was strong deviation in the West Siberian Arctic results, where the northern part of the Yamal- Gydan 
sector joined with northern Taimyr (Fig. 2 and 3, clusters 4A and 4B), whereas its southern part is connected to the European Arctic (clusters 2E and 2D). However, this can be explained by spread of a number of Arctic (sensu: belonging to the Arctic latitudinal group) species along the shelf from the east: most of them reached only Gydan, but a few expanded to the north of Yamal. These Arctic species are almost absent in the more southern parts of this sector. The wide occurrence of acidic peaty soils, which are not suitable for many Arctic species is one of the reasons for their absence in subzones $\mathrm{D}$ and $\mathrm{E}$ in the West Siberian Arctic, whereas these species are common in these southern subzones in the Taimyr region. On the other hand, in Yamal-Gydan, as well as in the East European Arctic, the Holocene expansion of Boreal forest into the tundra was the greatest (Khotinsky 1977) and explains the abundance of relict boreal species in the subzones E and D there, common with European taiga and forest-tundra floras.

[Fig. 3. Floristic differentiation of the Russian Arctic based on similarity of species composition of local floras.]

In the East Siberian province, the Anabar-Olenek and Kharaulakh subprovinces join and even connect with the southern part of Taimyr (Fig. 2 and 3, cluster 5B). One explanation is that more than 20 local floras were only recently studied by the authors of this paper in Anabar-Olenek and Taimyr. Several species previously known only from Kharaulakh (including Artemisia lagopus subsp. abbreviata Krasch. ex Korobkov, Taraxacum semitubulosum Jurtz., Carex trautvetteriana Kom.) were found in those localities (see also: Pospelova and Pospelov 2007). Naturally, this increased the similarity coefficients. However, such results should be treated with care. It could be just an artifact of numerical analysis, simply reflecting scarcity of local floras in the Anabar-Olenek subprovince for drawing reliable boundaries. The Kharaulakh subprovince on the right bank of the Lena River in spite of its very small area was considered by Yurtsev (1994) as central for the whole East Siberian province, providing a link to montane floras of North-East Asia. This subprovince is characterized by 
the presence of a number of subendemics of the Verkhoyansk Range. The 'value' of such species for phytogeographical conclusions is much higher, but in our statistical analysis all species were treated equally.

Two northernmost (subzone A) local floras were separated from all other floras (cluster 1) with a very low level of similarity. This is partially due to their paucity, but they also differ from others by geographical structure - only the Arctic latitudinal group is present and proportion of the Circumpolar subgroup reaches $75 \%$. This border was confirmed by analyses of many other variables, including taxonomical and geographical structure (Koroleva et al. 2008, 2010, 2012), that strengthens evidence of its high rank. Our results support the idea of distinguishing the High Arctic as a separate subprovince in much the same way as the polar desert zone was distinguished by Aleksandrova (1980). Further evidence of the unique character of the zonal vegetation in subzone A was recently shown in Daniëls et al. (2016).

\section{Longitudinal structure of local floras}

Longitudinal structures (i.e. compound and proportions of various phytogeographical groups or subgroups) were analyzed for 136 local floras from the Yamal-Gydan, Taimyr and Chukotka sectors of the Asian Arctic (six subprovinces) where the network is more dense and even (Koroleva et al. 2008, 2011). Both groups and subgroups were analyzed, however, only subgroups will be discussed in this paper, as these results better reflected differentiation (Koroleva et al. 2011). The absolute number of species increases in all groups and in many subgroups in local floras from the Yamal-Gydan sector to Chukotka, because in Chukotka, local floras are at least two times richer than in Yamal-Gydan (Yurtsev et al. 2002). Therefore, only changes in proportion of various subgroups are discussed here. Maps showing the proportion of each of 18 longitudinal geographic subgroups were presented and discussed in detail in Koroleva et al. (2008). Certain thresholds in values became apparent on these maps and allowed boundaries to be drawn. In certain areas abrupt changes were found in distribution of several subgroups; these approximated borders are shown in Fig. 4 (blue dotted line). The borders 
were also drawn between areas occupied by floras of different clusters obtained in the analysis of pairwise similarity of longitudinal structure (Fig. 5). The ranges of percentage of each longitudinal subgroup in floras belonging to one cluster are presented in Table 2. The boundaries obtained after the cluster analysis primarily reflect the zonal gradient in western sectors and the continentality-oceanity gradient in Chukotka (Fig. 6). However, some of them resemble those found by distribution of subgroups (Fig.4, compare blue and green dotted lines). All boundaries were compared with the borders of floristic subdivisions by Yurtsev (1994) (Fig. 4).

Both analysis of distribution of individual subgroups and analysis of similarity of longitudinal structure showed clear distinction of two western sectors from Chukotka (Fig.5, clusters 1 and 2 respectively).

[FIG 4. Floristic boundaries obtained through the analyses of the distribution of the longitudinal subgroups and similarity of longitudinal structure of local floras in (A) Yamal-Gydan and Taimyr sectors and in (B) Chukotkan sector]

[FIG. 5. Dendrogram of the similarity of proportions of longitudinal subgroups in the local floras]

[Table 2. Percentage of longitudinal geographical subgroups in the local floras (LF) in YamalGydan, Taimyr and Chukotka]

In Yamal-Gydan and Taimyr, proportions of all subgroups exhibited zonal trends decreasing northwards, except for the Circumpolar subgroup which increased. Longitudinal trends were found in all groups and were especially pronounced in groups with more narrow ranges (Koroleva et al. 2008). The proportion of the West Eurasian subgroup (representing 7-10\%) in Yamal local floras drops sharply in the eastern Gydan. In the same area, there was an increase in proportion of many eastern subgroups (for example, Asian, Middle Siberian, East-Asian and East Asian-American), which were poorly represented westwards. A sharp increase in these groups demarcated the border between 
Western and Eastern Taimyr and some of them also demarcated the area to the north of the Taimyr Lake (Table 2). The latter boundary was clearly shown also after depicting clusters $1 \mathrm{Ba}$ and $1 \mathrm{Bb}$ on the map (Fig. 5 and 6A). This border separates the mountainous floras of the Byrranga Mountains and adjacent highlands from the southern lowland floras.

[FIG. 6. Positions of local floras belonging to various clusters (Fig. 5) obtained through the analysis of their longitudinal structure]

In the Chukotkan sector, the borders found both in the analysis of representation of subgroups and in the analysis of similarity of longitudinal structure of local floras partly align with the subprovincial borders (Fig. 4B). For example, the border between Continental and Beringian Chukotka was supported both by distribution of the subgroups (such as, Chukotkan-American, ChukotkanAmerican-West Eurasian, Almost Circumpolar and Eurasian) and by cluster analysis (Fig. 5 and 6B, clusters 2Da and 2Db, see also: Table 2). However, several boundaries which were not reflected in the subdivision of Yurtsev (1994), were found as well. For example, the border between western and central parts of Chukotka was delimited by the distribution of the Asian, Eurasian, East Asian and Chukotkan subgroups, and also by all subgroups of the predominantly American group, although it was not reflected in the dendrogram (Fig.5, all floras were in cluster 2Db). All boundaries based on our analysis are shown in Fig. 4; however, their rank is still unclear: some of them are definitely below subprovincial level, but some probably indicate the necessity to alter the position of subprovincial borders.

\section{Re-inventory of local floras}

Nine sites were re-visited 20-70 years after initial study with the aim of determining changes in flora composition and species abundances (Fig. 7, Table 3 and 4). As there can be some uncertainty whether or not a species was found during the initial inventory, we assumed that changes occurred 
only if the number of new species and species that were not found during re-inventory (i.e., species which probably disappeared) was approximately $10 \%$ or more of the initial checklist (i.e. exceeds methodological error). To determine the trends in changes we compared the proportion of different latitudinal subgroups between the old and the new species checklists. A summary of the results is presented in Table 3.

In two revisited Eastern Taimyr local floras (Fig 7, sites 1 and 2; Tables 3 and 4), there was an increase of 33 species and 28 species, respectively. At both sites, 10-12 species were probably missed in previous surveys due to their rarity, however, most of the new species were found in the areas that had been well surveyed previously, as indicated in detailed field-notes or as parts of surveys of permanent plots. Therefore, there is a high level of confidence that these new species spread into the area after the first surveys.

In the local flora "Yamu-Neru" from the subzone D, latitudinal subgroups among new findings (see sectoral diagram on Fig.7, site 1) were represented in much the same proportions as in the original checklist. However, in the flora "Ary-Mas" from the subzone E (Fig. 7, site 2), a small increase (ca. $3 \%$ ) in the Boreal subgroup was recorded in the checklist, but $30 \%$ of new species belonged to the Boreal subgroup (see also Table 4). Notably, a new willow species Salix dasyclados auct. non Wimm. appeared there after the re-inventory in 2002. It was found in one of the permanent plots in 2013. For the flora in subzone D good indications of field routes and notes on species occurrences were available, therefore changes in frequency of occurrence were recorded for 49 species. Occurrence of twelve species of the Arctic latitudinal group decreased from 'sparse' to 'rare' since 1928. Among the 37 species with increased frequency of occurrence (from rare to sparse), both the Arctic and the Hypoarctic groups were equally represented.

[FIG. 7. Locations of nine re-visited local floras and proportions of latitudinal subgroups among new species]

[TABLE 3. Summary of re-inventory of nine local floras in the Russian Arctic] 
In the local flora near Tiksi harbour (Fig.7, site 4; Tables 3, 4), approximately 13 new species were found but it is likely that several species previously present in the area have disappeared. An increase in the Boreal (4\%) and Hypoarctic (3\%) groups was noted. However, many Boreal species are anthropochores, whereas among species that most likely spread naturally, Hypoarctic species predominate. Notably, several typical snow bed species belonging to the Arctic group were not found in the re-survey_including Phippsia algida (Sol.) R. Br., Ranunculus pygmaeus Wahlenb. and Minuartia biflora (L.) Schinz and Thell. (Sekretareva and Sytin, 2006). According to Tikhomirov et al. (1966), willows (Salix alaxensis (Andersson) Coville, S. lanata L., S. hastata L.) were sporadically growing on the lower parts of mountain slopes remote from the coast. In 2004, shrub copses were extensive along the lower parts of the slopes. The increase in occurrence of Artemisia lagopus subsp. abbreviata Krasch. ex Korobkov and Thymus extremus Klokov (from rare to sparse) was recorded as well. These species were characterized as xero-thermophilous (Arctic Flora of the USSR, 1960-1987).

The next three sites (Fig.7, sites 3, 5, 6; Table 3 and 4) were not initially studied with the local flora method but were visited and re-visited briefly, therefore species lists were most likely incomplete. Descriptions of daily routes were not available for these sites, so it is possible that the area initially explored was somewhat smaller or had slightly different configuration than the area that we investigated. These sites were included into the network only after our re-inventory, which resulted in a notable (50-80 species) increase in richness. However, as we only compare the proportion of various latitudinal groups among new findings and in the prior lists, these data are presented here as well. It is very unlikely that only certain groups were missed in previous surveys. In two southern localities ('Saskylakh' in subzone F and 'Chokurdakh in subzone E) $66-67 \%$ of species in new checklists belonged to the Boreal and Hypoarctic groups compared to approximately $60 \%$ in prior checklists. At both sites among new Boreal species there was a number of anthropochores found near the roads, which were unlikely to be missed in earlier surveys (Table 4). Notably, young tiny trees (less than $1 \mathrm{~m}$ height) of Larix cajanderi Mayr were recorded on the upper terraces. It is likely that they have spread 
in recent decades from the Indigirka floodplain where larch is present. In contrast, re-inventory of the area near Polyarnui village, located ca $100 \mathrm{~km}$ north of Chokurdakh, in subzone C Fig.7, site 6), did not indicate any increase in the Boreal group. Metaarctic and Hypoarctic species prevailed among new findings, but on the whole the latitudinal structure is much the same as it was in the old list (Table 4).

[Table 4. Number of new species in various latitudinal subgroups found in re-inventory of nine local floras (with examples of species in each subgroup)]

No changes in species composition and frequency of occurrences were found after re-inventory of local flora in central Yamal (Fig.7, site 7, Table 3). It is likely that 20 years is a relatively short timeframe for floral change. In the area near Dikson polar station (subzone B) (Fig.7, site 8, Table 3), no changes in species compositions were recorded either, however, a decrease was noted in frequency of occurrence and abundance of several Arctic and Arctic-alpine herbs, such as Papaver polare (Tolm.) Perfil., Draba spp., Eritrichium villosum (Ledeb.) Bunge, Saxifraga hirculus L., S. cespitosa L. (Matveeva and Zanokha 2013). In this case, the authors used a combined 5 point scale of abundance and frequency of occurrences, where 5 means that the species is common, occupies many different habitats and abundant, 1 means that the species was found 1-2 times, in solitary abundance, in one habitat type. For the above mentioned species this estimate changed from 3 to 2 . At another Western Taimyr site, 'Tareya' (Table 3, Fig. 7, site 9), almost 30 species were not found in 2010. However, the authors of the re-inventory (Matveeva et al. 2014) believe this was due to limited timeframe of their fieldwork and are confident that the species are still present in the area. That is probably the case- as the initial inventory from the field station 'Tareya' in the 1960-1970's was extremely thorough and catalogued local flora over several seasons. The majority of species missing in the re-inventory were previously found once and in solitary abundance. However, among the species which were not found in the re-inventory, latitudinal groups were present in approximately the same proportions as in the old checklist (e.g., dominance of the Arctic group), whereas among ten new species, Hypoarctic and 
Arctic-boreal species were clearly predominant (Table 4). Therefore we cannot agree with the authors' conclusion that no changes have occurred at that site. Additionally, as in Dikson, a decrease in abundance and frequency of occurrence (from 3 to 2) of herbs belonging to the Arctic group was recorded in meadows on steep slopes. However, the percent cover of the Metaarctic species Carex arctisibirica (Jurtz.) Czerep. in permanent plots increased almost twofold compared to values recorded in the 1960's. Abundance and frequency of occurrence of Carex concolor R.Br. and Arctagrostis latifolia (R.Br.) Griseb. also increased from 3 to 4.

\section{Discussion}

\section{Application of local floras network for floristic subdivision of the Arctic}

Cluster analysis performed on similarity of species composition and on similarity in proportions of various longitudinal groups showed clear differentiation of local floras of different sectors. However, boundaries in many areas did not coincide with those suggested by Yurtsev et al. (1978) and Yurtsev (1994). This was anticipated as the approaches for regionalization were principally different. Yurtsev's scheme was based on a divergence principle, descending from the high rank (floristic region) to the lower (provinces, subprovinces, districts). It was arbitrary, based on the broad knowledge of its author, who took into account the qualitative differences of various parts of the Arctic and the presence of differential and co-differential species. The use of quantitative characters for floristic subdivision was based on the convergence principle, which has an ascending order from lower to higher units (Malyshev et al. 2000). It is based on agglomerative clustering according to the similarity of certain features. We used species composition only for delineating floristic divisions, as genera showed little if any differentiation apart from zonal (Koroleva et al. 2010). However, for the Asian part of Russia, Malyshev et al. (2000) used similarity of genera composition in a phylogenetic subdivision attempt. The geographical structure of flora is a more general feature which has never been estimated quantitatively for floristic subdivision. Tolmatchev (1958) suggested that it could help to determine position and rank of the boundaries, as the predominating type of range determines the 
character of flora. Analysis of the local floras from selected sectors of the Arctic showed that it is a useful additional tool. Use of many variables can provide an optimal model for floristic subdivision.

The most notable difference in subdivision based on our numerical approach was that zonal (i.e., latitudinal) differentiation partly overlaps the sectoral (i.e. longitudinal) differences. Yurtsev et al. (1978) consciously avoided reflecting a zonal gradient in the scheme of sectoral division. They considered the importance of the longitudinal gradient as reflecting both specific physiography and natural history of the given sector and also continentality of climate. They suggested using latitudinal differentiation to distinguish floristic units of the lower rank within subprovinces. Some of the boundaries that we found in Chukotka supported this suggestion (compare with: Yurtsev et al. 1979). However, Aleksandrova (1980) combined zonal and sectoral divisions into one scheme of geobotanical division of the Arctic. Malyshev et al. (2000) used a numerical approach for the floristic subdivision of Asian Russia and got the same combination.

Our analysis revealed certain 'problem' areas. The position of the border between the YamalGydan and the Taimyr subprovinces needs further investigation, as well as the boundary between Western and Eastern Taimyr. These areas probably should belong to different subprovinces. Aleksandrova (1980) using other criteria classified eastern and western parts of the sub-Arctic tundra in Taimyr into two different provinces. The Arctic tundra of Taimyr in her scheme was joined together with the Arctic tundra of Yamal-Gydan and they were part of a third province. Our analysis was based on floristic similarity alone and showed very similar differentiation.

Different results obtained by analyzing different variables underpin the necessity for more field research in the eastern part of the Gydansky Peninsula. This would enable a more precise determination of the border between the European-West Siberian and the East Siberian provinces. Yurtsev (1994) drew this border through the Enisei Bay as it demarcated different geographical regions and also he considered the distribution of differential species. However, many of these species have been found later in the north-eastern part of the Gydansky Peninsula, including species such as Bistorta plumosa (Small) Greene, Saxifraga bronchialis L., S. hirculus L., S. oppositifolia L., S. 
spinulosa Adams, Androsace triflora Adams, Senecio resedifolius Less. (Khitun 1998). In a floristic subdivision of Asian Russia based on generic similarity (Malyshev et al. 2000), the eastern part of Gydan was also joined with Taimyr.

On the other hand, Taimyr itself seems to be rather heterogeneous. The eastern part of Taimyr was the westernmost part of Megaberingia according to Yurtsev (1972) and most probably was, at least partly, ice-free during the Pleistocene glaciations (Möller et al. 1999). The modern Eastern Taimyr flora formed under the influence of Pleistocene marine regressions and transgressions, and due to species migrations to this region from south and east (Tolmatchev and Yurtsev 1970; Abbot and Brochmann 2003). Migrations along the shelf during the cryo-aridic periods resulted in enrichment of its flora with East Asian and East Asian-West American species and provided closer links with floras of Eastern Asia (Yurtsev 1972). The presence of such species as Potentilla anachoretica Soják, Artemisia arctisibirica Korobkov and Braya pilosa Hook, strengthen this evidence. At the same time there were migrations northwards from the mountains of East Siberia (Yurtzev 1972), which explains how species such as Lesquerella arctica (Wormsk. ex Hornem.) S.Wats, Astragalus schelichovii Turcz., Oxytropis adamsiana (Trautv.) Jurtz. spread into the Eastern Taimyr.

After the Pleistocene glaciations, the western part of Taimyr, which belongs to basins of the Enisei and the Pyasina Rivers, experienced massive migration of boreal species from the south, especially along the Enisei River valley. Also, intensive floristic exchange took place along the North Siberian lowland. As a result, the western part of Taimyr was enriched with the species that reach their eastern limit there (including Larix sibirica Ledeb., Salix lapponum L., S. phylicifolia L., Arabis alpina L., Pedicularis compacta Steph.) and are more closely connected with European floras (Pospelova 2007).

Yurtsev (1994) made an essential change in his scheme compared to Yurtsev et al. (1978) and distinguished Wrangel Island as a separate subprovince (it was considered as a part of Continental Chukotka in the earlier version). He also distinguished the Amguema transitional area. These subdivisions are also supported by our analysis. 
Longitudinal trends generally reflect the continentality-oceanity gradient (Qian 1999). At a local flora level this tendency can be masked by a difference in physiography (as we observed in certain parts of Chukotka) but overall it is reflected in the distribution of several longitudinal groups (particularly in Chukotka). The glacial history of the region and migrations are the crucial factors affecting longitudinal changes in the Arctic (Hultén 1937; Abbott and Brochmann 2003). However, zonal changes exhibit a stronger influence and are reflected even in the distribution of longitudinal elements.

The need to revise the existing scheme of delimitation of the Arctic is obvious as new data have been collected since the 1990's. Our results indicate that a compromise between numerical methods and expert evaluation (based on a set of differential species) could be a solution. The use of typological characteristics of floras is likely to be a helpful additional tool for regionalization. However, the gaps in the local flora network did not allow complete analysis.

\section{Re-inventory of local floras}

The method of local floras was not designed for monitoring, therefore our main purpose was to test if monitoring at local flora level is possible at all. Results of the re-inventory of the local floras cannot be properly analyzed yet as there are too few sites. However, our preliminary results show that monitoring at the level of local floras is possible, although logistical constraints and the absence of comprehensive documentation from the initial surveys makes evaluation of results difficult. Nevertheless, our results showed that there were regional and subzonal differences. Notably, the greatest changes were found in the two southernmost local floras with a particular increase in the number of boreal species. This is in agreement with previous research that the forest-tundra ecotone is one of the most sensitive areas for predicted climate change (Callaghan et al. 2013). It is also notable that many boreal species are anthropochores. Harsh climatic conditions seem to be the main reason that little or no change was observed in floras in subzones C and D. Even after 70 years, little change was observed in latitudinal structure. It is likely, that the climatic barrier is still too harsh for southern 
species. However, changes in species occurrence noted at several sites, and the disappearance of snowbed species at one site, show that changes are ongoing. Although these results are not confirmed statistically, they support findings from other regions. The disappearance of several snowbed species in the Tiksi region could be connected with more rapid snowmelt and increased competition with grasses and dwarf-shrubs. This conclusion corresponds with the results of warming experiments with enhanced temperature in open-top chambers, showing that snow bed vegetation and particularly Ranunculus nivalis L. may suffer a competitive disadvantage (Molau 2001). In contrast, an increase in the abundance and frequency of willows was recorded. Our records on the increased frequency of willows, the appearance of shrub species and the expansion of trees from the flood plains to the interfluves provide evidence of the 'greening of the Arctic' phenomenon and 'shrubification' which are widely discussed in literature (Myers-Smith et al. 2011; Elmendorf et al. 2012; Walker et al. 2012; Callaghan et al. 2013).

\section{Conclusion}

Documenting Arctic plant species and their distributions is important for predicting possible changes in Arctic terrestrial ecosystems, however there are large gaps in available information (Walker et al. 2013). The local flora approach provides information which allows the analysis of spatial distribution and differentiation of biodiversity at local and regional scales. Changes in species composition along the zonal gradient in different sectors of the Asian Arctic can be easily traced and used for predicting possible changes. The dataset used in our study allows the analysis of gradients of taxonomic diversity and the distribution of geographical elements, and also refines floristic subdivision.

Unfortunately, opportunities for monitoring at the level of local floras based on old surveys are relatively limited. However, the change analysis conducted at nine selected locations showed the feasibility and value of such studies to examine changes in biodiversity as result of climate and anthropogenic changes. Taking into account the difficulties in reaching remote locations throughout the Arctic and also shortage of qualified personnel, incorporating the local floras approach to existing 
network of Arctic observatories would be advantageous (Walker et al. 2016). Yurtsev (1997), proposing the idea of monitoring at the local flora level, underpinned the role of research stations and nature reserves where floristic inventories are repeatedly held. Complementary studies of local floras in the surroundings of existing stations can provide additional material for monitoring and modelling.

Naturally, the method should be modernized as a number of technical tools are easily available now. Use of GIS and remote sensing data can provide a complete representation of landscape changes at each locality. Accurate documentation should be obligatory parts of any survey and should include coordinates of the base camp, GPS tracking of daily routes, coordinates and permanent marking of all relevé plots and GPS coordinates of all rare species found in the area. Repeated photographs have proved to be very good visual evidence of changes (Villarreal et al. 2012). A combined 5 point scale of species abundances and occurrences used by some authors (Matveeva et al. 2014; Rebristaya and Khitun 1998) helps somewhat to avoid subjectivity. This scale together with estimation of percentage cover in a representative set of relevés in various habitat types would provide more objective information about species abundance.

The work on integrating the Russian Arctic local floras database in GIS has just started. Currently, only the Taimyr data have been integrated into GIS and available via www.byrranga.ru. Although specific vegetation studies have not been conducted at the majority of the local flora sites, detailed descriptions of communities in different habitats were performed at several localities, hence the local flora network can also contribute to the Arctic Vegetation Archive (Walker 2014). For some of the local floras included in the network cryptogamic data were collected as bryologists and lichenologists were working there.

Local flora data can be particularly valuable in elaborating Arctic biodiversity conservation strategies within the frames of the policies and programs of the Conservation of Arctic Flora and Fauna (CAFF) program of the Arctic Council, as it can help to recognize endangered species and hotspots of biodiversity. 


\section{Acknowledgements}

The work was supported by grants of RFBR 10-04-01087a, 13-04-01682a and is a part of research conducted by Komarov Botanical Institute within the topic No 01201465701“Spatial and Temporal Changes in the Russian Far North Plant Cover". Research of A. Zverev was supported by the grant issued under the Agreement No 14.B25.31.0001 with the Ministry of Education and Science of the Russian Federation, dated 24 June 2013 (BIO-GEO-CLIM). Comments of two anonymous reviewers and the Editor helped to improve the paper greatly.

\section{References}

Abbott, R.J., and Brochmann, C. 2003. History and evolution of the arctic flora: in the footsteps of Eric Hultén. Molecular Ecology, vol. 12, pp. 299-313.

Andreev, V.N., Perfiljeva, V.I., and Nahabtzeva, V.N. 1980. Flora of the surroundings of Saskylakh settlement on the Anabar River (North-West Yakutia). Botanicheskii Zhurnal, vol. 65, no. 11, pp. 1560-1568. (in Russian)

Aleksandrova, V.D. 1980. The Arctic and Antarctic: their division into geobotanical areas, Cambridge Univ Press, Cambridge.

Arctic flora of the USSR: vols. I-X 1960-1987, Nauka, Leningrad. (in Russian).

Balandin, S.A. 2008. Evaluating of Monitoring Local Floras in Arctic Russia. In Proceedings of the Fourth International Conservation of Arctic Flora and Fauna (CAFF) Flora Group Workshop, 15-18 May 2007, Tørshavn, Faroe Islands. CAFF Technical Report No. 15, ed. SS Talbot, Akureyri, Iceland, pp. 29-33.

Baranova, O.G. 1994. Comparative study of Udmurtian local floras. In Actual problems of comparative studies of floras. Edited by B.A. Yurtsev, Nauka Press, St.-Petersburg, pp. 97-105. (in Russian).

Boch, M.S., and Tsaryova, V.T. 1974. On the flora of the Indigirka river low reaches (within the limits of tundra zone). Botanicheskii Zhurnal, vol. 59, no. 6, pp. 839-849. (in Russian). 
Bubyreva, V.A. 1998. Comparison of local floras of taiga and tundra on the northern macro-slope of the Russian Plain. In Study of biological diversity by the methods of comparative floristics. Edited by B.A. Yurtsev. NIIH Press, St.-Petersburg, pp. 70-86. (in Russian).

Callaghan, T.V., Jonasson, C., Thierfelder, T., Yang, Z., Hedenes, H., Johansson, M., Molau, U., Van Bogaert, R., Michelsen, A., Olofsson, J., Gwynn-Jones, D., Bokhorst, S., Phoenix, G., Bjerke, J.W., Tømmervik, H., Christensen, T.R., Hanna, E., Koller, E.K., and Sloan, V.L. 2013. Ecosystem change and stability over multiple decades in the Swedish subarctic: complex processes and multiple drivers. Philosophical Transactions of the Royal Society B 368: 20120488. Available from: <http://dx.doi.org/10.1098/rstb.2012.0488> [11 mars 2014]

CAVM Team 2003. Circumpolar Arctic Vegetation Map. Scale 1:7 500 00. U.S. Fish and Wildlife Service, Anchorage, Alaska

Chinenko, S.V. 2008. Local floras of the eastern part of the northern coast of Kola Peninsula in comparison with local floras of adjacent regions. Botanicheskii Zhurnal, vol. 93, no. 1, pp. 6081. (in Russian).

Chinenko, S.V. 2013. Comparison of the local floras of the eastern part of the northern coast of the Kola Peninsula and adjacent regions: taxa and life form composition. Botanicheskii Zhurnal, vol. 98, no. 1, pp. 1-20 (in Russian).

Cramer, W., Yohe, G.W., Auffhammer, M., Huggel, C., Molau, U., da Silva Dias, M.A.F., Solow, A., Stone, D.A., and Tibig, L. 2014. Detection and attribution of observed impacts, in Climate Change 2014: Impacts, Adaptation and Vulnerability. Part A: Global and Sectoral Aspects. Contribution of Working Group II to the Fifth Assessment Report of the Intergovernmental Panel on Climate Change, eds CB Field, VR Barros et al. Cambridge University Press, Cambridge, United Kingdom and New York, NY, USA, pp. 979-1037.

Daniëls, F.J.A., Elvebakk, A., Matveyeva, N.V. and Mucina, L. 2016, The Drabo corymbosaePapaveretea dahliani - a new vegetation class of the High Arctic polar deserts, Hacquetia, vol. 15 , no. 1, pp.5-13. 
Egorova, A.A., Vasiljeva, I.I., Stepanova, N.A., and Fesko, N.N. 1991. Flora of the tundra zone of Yakutia. Yakutian Science Centrum Ac Sc USSR Press, Yakutsk. (in Russian).

Elmendorf, S.C., Henry, G.H.R., Hollister, R.D., Björk, R.G., Bjorkman, A.D., Callaghan, T.V., Collier, L.S., Cooper, E.J., Cornelissen, J.H.C., et al. 2012. Global assessment of experimental climate warming on tundra vegetation: heterogeneity over space and time. Ecology Letters, vol. 15, pp. 164-175.

Elven, R. (ed.) 2007. Annotated Checklist of the Panarctic Flora (PAF). Vascular plants. Available from: <http://nhm2.uio.no/paf>. [10 March 2015].

Flora of Siberia: vols. 1-13 1987-1997, Nauka, Novosibirsk. (in Russian).

Hill, T., and Lewicki, P. 2007. Statistics Methods and Applications, StatSoft, Tusla.

Hultén, E. 1937. Outline of the history of the arctic and boreal biota during the Quaternary period, Bokförlags Aktiebolaget Thule, Stockholm.

Hultén, E., and Fries, M. 1986. Atlas of the North European vascular plants, I-III, Koeltz, Königstein.

Grytnes, J.A., Birks, H.J.B., and Peglar, S.M. 1999. Plant species richness in Fennoscandia: evaluating the relative importance of climate and history, Nordic Journal of Botany, vol. 19, no. 4, pp. 489-503.

Kharkevich, S.S. (ed.) 1985-1996. Vascular Plants of the Soviet Far East: vols. 1-8. Nauka, Leningrad

Khitun, O.V. 1998. Comparative analysis of local and partial floras in two subzones of West Siberian Arctic (Gydansky and Tazovsky peninsulas). In Study of biological diversity by the methods of comparative floristics. Edited by B.A. Yurtsev. NIIH Press, St.-Petersburg, pp. 173-201. (in Russian).

Khitun, O.V., Koroleva, T.M., Chinenko, S.V., Petrovsky, V.V., Pospelova, E.B., Zverev, A.A. 2013. Application of Russian Arctic local flora database to the issues of Arctic biodiversity conservation. In Arctic Vegetation Archive workshop, Krakow, Poland, April 14-16, 2013. CAFF Proceedings Report no. 10. Edited by D.A. Walker, A.L. Breen, M.K. Raynolds and M.D. Walker. Akureyri, Iceland, pp. 52-56 
Khotinsky, N.A .1977. Holocene of the Northern Eurasia. Nauka, Moscow (in Russian)

Kier, G., Mutke, J., Dinerstein, E., Ricketts, T., Küper, W., Kref, H., and Barthlott, W. 2005. Global patterns of plant diversity and floristic knowledge. Journal of Biogeography, vol. 32, no. 7, pp. 1107-1116.

Koroleva, T.M., Zverev, A.A., Katenin, A.E., Petrovskii, V.V., Rebristaya, O.V., Khitun, O.V., Khodachek, E.A., and Chinenko, S.V. 2008. Longitudinal geographical structure of local and regional floras of the Asian Arctic, paper 1. Botanicheskii Zhurnal, v. 3, no. 2, pp. 193-220 (in Russian).

Koroleva, T.M., Zverev, A.A., Katenin, A.E., Petrovskii, V.V., Pospelova, E.B., Rebristaya, O.V., Khitun, O.V., and Chinenko, S.V. 2010. Comparative study of local floras variables based on biodiversity monitoring network in the Russian Arctic and Subarctic. Transactions of Ryazan Division of Russian Botanical Society. Issue 2, part 2, pp. 92-107 (in Russian).

Koroleva, T.M., Zverev, A.A., Katenin, A.E., Petrovskii, V.V., Rebristaya, O.V., Khitun, O.V., Khodachek, E.A., and Chinenko, S.V. 2011. Longitudinal geographical structure of local and regional floras of the Asian Arctic, paper 2. Botanicheskii Zhurnal, v. 96, no. 2, pp. 145-169 (in Russian).

Koroleva, T.M., Zverev, A.A., Katenin, A.E., Petrovskii, V.V., Pospelova, E.B., Pospelov, I.N., Rebristaya, O.V., Khitun, O.V., and Chinenko, S.V. 2012. Latitudinal geographical structure of local floras of the Asian Arctic: analysis of distribution of groups and fractions, Botanicheskii Zhurnal, vol. 97, no. 9, pp. 69-89. (in Russian).

Malyshev, L.I. 1975. Quantitative analysis of flora: spatial diversity, species richness and representativeness of studied areas, Botanicheskii Zhurnal, vol. 60, no. 11, pp. 1537-1550. (in Russian).

Malyshev, L.I., Baikov K.S., and Doronkin. V.M. 2000.'Floristic subdivision of Asian Russia based on quantitative features', Krylovia, vol. 2, no 1, pp. 3-16 
Matveeva, N.V. 1978. Vegetation of the surroundings of Taimyr biogeocoenological station. In Structure and functions of biogeocoenoses of Taimyr tundra. Edited by BA Tikhomirov. Nauka, Leningrad, pp. 72-113. (in Russian).

Matveeva, N.V., and Zanokha, L.L. 1997. Flora of the vascular plants of the NW part of the Taimyr peninsula. Botanicheskii Zhurnal, vol. 82, no. 12, pp. 1-20. (in Russian).

Matveeva, N.V., and Zanokha, L.L. 2013. Stability of vegetation cover and essential transformation of landscape in tundra of Western Taimyr. In Biodiversity of the Far North ecosystems: inventory, monitoring, conservation: Proceedings of II all-Russian Conference, Syktyvkar, 3-7 June 2013, Komi Scientific center, Syktyvkar, pp. 100-108. (in Russian).

Matveeva, N.V., Zanokha, L.L., and Yanchenko, Z.A. 2014.Changes in vascular plant flora in the area of the Taimyr Biogeocenological field station (mid-course of the Pyasina river, Western Taimyr) from 1970 to 2010. Botanicheskii Zhurnal, vol. 99, no. 8, pp.841-867

Molau, U. 2001. Tundra plants responses to experimental and natural temperature changes. Memoirs of National Institute of Polar Research, spec. iss. 54, pp. 445-466.

Myers-Smith, I., Forbes, B.C., Wilmking, M., Hallinger, M., Lantz, T., Blok, D., Tape, K.D., MaciasFauria, M., Sass-Klaassen, U., et al. 2011. Shrub expansion in tundra ecosystems: dynamics, impacts and research priorities. Environmental Research Letters, vol. 6 (045509), no. 4, doi: 10.1088/1748-9326/6/4/045509. Available from: <http://iopscience.iop.org/17489326/6/4/045509>. [7 March 2015].

Möller, P., Bolshiyanov, D.Yu. and Bergsten, H. 1999. Weichselian geology and paleoenvironmental history of the central Taymyr Peninsula, Siberia, indicating no glaciation during the last global glacial maximum. Boreas, vol. 28, pp. 92-114.

Naumenko, N.I. 2008. Flora and vegetation of Southern Trans-Urals. Kurgan University Press, Kurgan. (in Russian).

Qian, H. 1998. Large-scale biogeographic patterns of vascular plants richness in North America: an analysis at generic level. Journal of Biogeography, vol. 25, no. 5, pp. 829-836. 
Qian, H. 1999. Spatial pattern of vascular plant diversity in North America North of Mexico and its floristic relationship to Eurasia. Annals of Botany, vol. 83, no. 3, pp. 271-283.

Qian, H., Song, J.S., Krestov, P., Guo, Q., Wu, Z., Shen, X., and Guo, X. 2003. Large-scale phytogeographical patterns in East Asia in relation to latitudinal and climatic gradients. Journal of Biogeography, vol. 30, no. 1, pp. 129-141.

Penev, L. 1997. Concrete biotas - a neglected concept in biogeography? Global Ecology and Biogeography Letters, vol. 6, no. 2. pp. 91-96.

Polozova, T.G., and Tikhomirov, B.A. 1971. Vascular plants of the Taimyr station (right bank of the Pyasina river, near the Tareya mouth, Western Taimyr. In Biogeocoenoses of Taimyr tundra and their productivity. Edited by BA Tikhomirov, Nauka, Leningrad, pp. 161-184. (in Russian).

Pospelov, I.N., and Pospelova, E.B. 2001. A new revision of Bikada (Yamu-Neru, Taimyr) river vascular flora after 70 years. Botanicheskii Zhurnal, vol. 86, no. 5, pp. 13-29. (in Russian).

Pospelova, E.B. 2007. On the heterogeneity of flora of Taimyr subprovince of Arctic floristic region. Botanicheskii Zhurnal, vol. 92, no. 12, pp. 1836-1856. (in Russian).

Pospelova, E.B., and Pospelov, I.N. 2005. Program of long-term monitoring of local floras in the Arctic: additions and changes in Ary-Mas flora (Eastern Taimyr). Botanicheskii Zhurnal, vol. 90, no. 2, pp. 145-164. (in Russian).

Pospelova, E.B., and Pospelov, I.N. 2007. Vascular Plants Flora of Taimyr and Adjacent Territories, part 1. Annotated list of species and general analysis, KMK Press, Moscow

Renkonen, O. 1938. Statistisch-ökologische Untersuchungen über die terrestrische Käferwelt der finnischen Bruchmoore. Annales Botanici Societatis Zoologicae-Botanicae Fennicae "Vanamo", vol. 6, no. 1, pp. 1-231.

Rebristaya, O.V. 1977. Flora of the eastern part of Bolshezemelskaya tundra. Nauka Press, Leningrad. Rebristaya, O.V. 2013. Flora of the Yamal Peninsula. Modern state and history of formation. Publishing house of ETU, St.-Petersburg. (in Russian). 
Rebristaya, O.V. and Khitun, O.V. 1998. Botanical-geographical specific of flora of Central Yamal, Botanicheskii Zhurnal, vol. 83, no. 7, pp. 37-52. (in Russian).

Rosenzweig, M. 1995. Species diversity in space and time, Cambridge University Press, Cambridge.

Sekretareva, N.A. 1999. The Vascular Plants of the Russian Arctic and Adjacent Territories. PentSoft, Sofia, Moscow.

Sekretareva, N.A. and Sytin, A.K. 2006. Monitoring of flora of Tiksi bay vicinities (Arctic Yakutia). Botanicheskii Zhurnal, vol. 91, no. 1, pp. 3-22. (in Russian).

Sergienko, V.G. 2013. Concrete floras of the Kanin-Mezenski region. KMK Scientific Press Ltd., St.Petersburg-Moscow. (in Russian).

Sheljag-Sosonko, Y.I. 1980. About local flora and local flora method. Botanicheskii Zhurnal, vol. 65, no. 6, pp. 761-774. (in Russian).

Shmidt, V.M. 1972. About the area of concrete flora. Vestnik of Leningrad State University, no. 3, pp. 57-66. (in Russian).

Sneath, R.H.A., and Sokal, R.R. 1973. Numerical Taxonomy, WH Freeman and Company, San Francisco

Talbot, S.S., Leblanc, M., and Aiken, S.G. 2008. Floristic subregions of the Canadian Arctic Archipelago. In Proceedings of the Fourth International Conservation of Arctic Flora and Fauna (CAFF) Flora Group Workshop, 15-18 May 2007, Tørshavn, Faroe Islands. CAFF Technical Report No. 15. Edited by S.S. Talbot. Akureyri, Iceland, pp. 42-45.

Tikhomirov, B.A., Petrovsky, V.V., and Yurtsev, B.A. 1966. Flora of the Tiksi Bay vicinities (Arctic Yakutia). In Plants of Siberia and Far East. Edited by B.A. Tikhomirov. Nauka Press, Leningrad, pp. 7-40. (in Russian).

Tolmatchev, A.I. 1931. About the methods of comparative floristics' investigations. 1. Flora concept in comparative floristics. Zhurnal Russkogo botanicheskogo obschestva (Journal of Russian Botanical Society), vol. 16, no. 1, pp. 111-124. (in Russian). 
Tolmatchev, A.I. 1932. Flora of the central part of Eastern Taimyr. Trudy Poljarnoi komissii AN SSSR (Works of Polar Comission AS USSR), part I, no. 8, pp. 1-126; part II, no. 13, pp. 1-75. (in Russian).

Tolmatchev, A.I. 1958. Species Areal and its development. In A Problem of Species in Botany, issue 1, Moscow - Leningrad, pp. 293-316. (in Russian)

Tolmatchev, A.I. 1974. Introduction to phytogeography, Leningrad State University Press, Leningrad. (in Russian).

Tolmatchev, A.I., and Yurtsev, B.A. 1970. History of the Arctic flora in connection with the history of the Arctic ocean, in Arctic Ocean in the Cenozoic, Hydrometeoizdat, Leningrad, pp. 87-100 (in Russian)

Vargina, N.E. 1978. Vascular plants flora. In Ary-Mas. Natural conditions, flora and vegetation of the northernmost forest outpost. Nauka, Leningrad, pp. 65-86. (in Russian).

Villarreal, S., Hollister, R.D., Johnson, D.R., Lara, M.J., Webber, P.J. and Tweedie, C.E. 2012. Tundra vegetation change near Barrow, Alaska (1972-2010). Environmental Research Letters, vol. 7 (015508), no. $1, \quad$ doi: 10.1088/1748-9326/7/1/015508. Available from: $<$ http://iopscience.iop.org/1748-9326/7/1/015508/>. [16 March 2016].

Walker, D.A. 2014. Towards a pan-Arctic Vegetation Archive and classification: Two recent workshops. IAVS Bulleten, 2014/1, pp. 12-16.

Walker, D.A., Epstein, H.E., Raynolds, M.K., Kuss P., Kopecky, M.A., Frost, G.V., Daniëls, F.J.A., Leibman, M.O., Moskalenko, N.G., Matyshak, G.V., Khitun, O.V., Khomutov, A.V., Forbes, B.C., Bhatt, U.S., Kade, A.N., Vonlanthen, C.M., and Tichy, L. 2012. Environment, vegetation and greenness (NDVI) along the North America and Eurasia Arctic transects. Environmental Research Letters, vol. 7 (015504), no. 1, doi: 10.1088/1748-9326/7/1/015504. Available from: $<$ http://iopscience.iop.org/1748-9326/7/1/015504/>. [11 March 2015].

Walker, D.A., Alsos, I.G., Bay, C., Boulanger-Lapointe, N., Breen, A.L., Bültmann, H., Christensen, T., Damgaard, C., Daniëls, F.J.A., Hennekens, S., Raynolds, M.K., Le Roux, P.C., 
Luoto, M., Pellissier, L., Peet, R.K., Schmidt, N.M., Stewart, L., Virtanen, R., Yoccoz, N.G. and Wisz, M.S. 2013. Rescuing Valuable Arctic Vegetation Data for Biodiversity Models, Ecosystem Models and a Panarctic Vegetation Classification, Arctic, vol. 66, no. 1, pp. 133137.

Walker, D.A., Daniëls, F.J.A., Alsos, I., Bhatt, U.S., Breen, A.L., Buchhorn, M., Bültmann, H., Druckenmiller, L.A., Edwards, M.E., Ehrich, D., Epstein, H.E., Gould, W.A., Ims, R.A., Meltofte, H.,Raynolds, M.K., Sibik, J., Talbot, S.S. and Webber, P.J. 2016. Circumpolar Arctic vegetation: a hierarchic review and roadmap toward an internationally consistent approach to survey, archive and classify tundra plot data. Environmental Research Letters, vol. 11 (2016) 055005), doi: 10.1088/1748-9326/11/5/055005. Available from: http://iopscience.iop.org/article/10.1088/1748-9326/11/5/055005 [20 June2015]

Yurtsev, B.A. 1972. Phytogeography of Northeastern Asia and the problem of transberingian floristic interrelations. In Floristics and Paleofloristics of Asia and Eastern North America. Edited by A. Graham. Elsevier, Amsterdam, pp. 19-54.

Yurtsev, B.A. 1975. Some tendencies of development of the concrete floras method. Botanicheskii Zhurnal, vol. 60, no. 1, pp. 69-83. (in Russian).

Yurtsev, B.A. 1982. Flora as a natural system. Bulletin MOIP: Biology series, vol. 87, no. 4, pp. 3-22. (in Russian).

Yurtsev, B.A. 1987. Elementary natural floras and basic units of comparative floristics. In Theoretical and methodogical problems of comparative floristics. Edited by B.A. Yurtsev. Nauka Press, Leningrad, pp. 47-66. (in Russian).

Yurtsev, B.A. 1994. Floristic division of the Arctic. Journal of Vegetation Science, vol. 5, no. 6, pp. 765-776.

Yurtsev, B.A. 1997. Monitoring of biodiversity at the level of local floras. Botanicheskii Zhurnal, vol. 82, no. 6, pp. 40-69. (in Russian). 
Yurtsev, B.A., Katenin, A.E., Koroleva, T.M., Kucherov, I.B., Petrovskii, V.V., Rebristaya, O.V., Sekretareva, N.A., Khitun, O.V., and Khodachek, E.A. 2001, An attempt of a biodiversity monitoring network creation in the Asian Arctic at the level of local flora: zonal trends. Botanicheskii Zhurnal, vol. 86, no. 9, pp. 1-27. (in Russian).

Yurtsev, B.A., Koroleva, T.M., Petrovskii, V.V., Polozova, T.G., Zhukova, P.G., and Katenin, A.E. 2010. Checklist of Flora of the Chukotkan Tundra, Saint-Petersburg, VVM Publishing. 628 p.

Yurtsev, B.A., Zverev, A.A., Katenin, A.E., Koroleva, T.M., Kucherov, I.B., Petrovskii, V.V., Rebristaya, O.V., Sekretareva, N.A., Khitun, O.V., and Khodachek, E.A. 2002. Gradients of taxonomical parameters of local and regional floras of the Asian Arctic (in the net of biodiversity monitoring sites). Botanicheskii Zhurnal, vol. 87, no. 6, pp. 1-28. (in Russian).

Yurtsev, B.A., Zverev, A.A., Katenin, A.E., Koroleva, T.M., Petrovskii, V.V., Rebristaya, O.V., Sekretareva, N.A., Khitun, O.V., and Khodachek, E.A. 2004. Spatial structure of species diversity of local and regional floras in the Russian Arctic, Botanicheskii Zhurnal, vol. 89, no. 11, pp. 1689-1726. (in Russian).

Yurtsev, B.A., Petrovskii, V.V., Korobkov, A.A., Koroleva, T.M., and Razzhivin, V.Y. 1979. Survey of Chukotkan vascular plants geographical distribution, part 1, Bulletin MOIP: Biology series, vol. 84, no. 5, pp. 111-122; part 2, no. 6. pp. 74-83. (in Russian).

Yurtsev, B.A., and Semkin, B.I. 1980. Study of local and partial floras by mathematical methods, Botanicheskii Zhurnal, vol. 65, no. 12, pp. 1706-1718. (in Russian).

Yurtsev, B.A., Tolmachev, A.I., and Rebristaya, O.V. 1978. Floristic delimitation of the Arctic, in The Arctic floristic region, ed. BA Yurtsev, Nauka Press, Leningrad, pp. 9-104. (in Russian).

Zanokha, L.L. 1987. The experience of vascular plant partial floras analysis in the south tundra subzone of Taimyr, Botanicheskii Zhurnal, vol. 72, no. 7, pp. 925-932. (in Russian).

Zverev, A.A. 1998. Comparative analysis of floras with the help of computer system IBIS, in Study of biological diversity by the methods of comparative floristics, ed. BA Yurtsev, NIIH Press, St.Petersburg, pp. 284-288. (in Russian). 
Zverev, A.A. 2007. Information technologies in study of vegetation, TML Press, Tomsk. (in Russian) 
Table Headers

Table 1. Description of phytogeographical elements (longitudinal and latitudinal groups and subgroups) in the Russian Arctic flora

Table 2. Percentage of longitudinal geographical subgroups in local floras (LF) in Yamal-Gydan, Taimyr and Chukotka.

Table 3. Summary of re-inventory of nine local floras in the Russian Arctic.

Table 4. Number of new species in various latitudinal subgroups found in re-inventory of nine local floras (with examples of species in each subgroup)

Figure Captions

Figure 1. The Russian Arctic and Subarctic local floras network.

Provinces and subprovinces (Yurtsev 1994): I, European-West Siberian Province, including KaninPechora (KP), Ural-Novaya Zemlya (UZ) and Yamal-Gydan (YG) subprovinces; II, East Siberian Province, including Taimyr (Ta), Anabar-Olenek (AO), Kharaulakh (Kh) and Yana-Kolyma (YK); III, Chukotka province, including Continental Chukotka (CC), Wrangel Island (CW), Southern Chukotka (CS), Beringian Chukotka (CB). Kola-Karelian (KK) subprovince was not included by Yurtsev into the Arctic floristic region.

Figure 2. Dendrogram of pair-wise species composition similarity of 240 local floras in the Russian Arctic.

The various clusters are indicated by numbers, letters and color. Each local flora name is coded by the abbreviation of subprovince name (as in Fig.1, but "ya" for the Yamal-Gydan subprovince and "ha " for the Kharaulakh subprovince) and the number. In the database all local floras are numbered in serial order separately in each subprovince. Similarity coefficient (1) values are represented in percentage scale.

Figure 3. Differentiation of the Russian Arctic based on species composition similarity in local floras.

The various clusters obtained in the dendrogram (fig. 2) are shown by the same color and number on the map; sub-clusters are showed by different shades.

Figure 4. Floristic boundaries obtained through the analyses of the distribution of the longitudinal subgroups and similarity of longitudinal structure of local floras in (A) Yamal-Gydan and Taimyr sectors and in (B) Chukotkan sector.

Arrows indicate some of the boundaries obtained in the analyses: [1] A boundary between northern and southern parts of Yamal, Gydan and Taimyr, roughly reflecting the border between the Arctic proper and the Hypoarctic (i.e., between subzones $\mathrm{C}$ and D), the borders below it roughly correspond to the border between the subzones D and E; [2] A border separating eastern part of Gydan from the rest of the YamalGydan subprovince; [3] A border along the Pyasina River separating Western and Eastern Taimyr; [4] A boundary north of the Taimyr Lake; [5] A border between western and central parts of Continental 
Chukotka and Beringian Chukotka; [6] A border, separating the northern coast of Continental Chukotka; [7] Borders indicating Amguema area; [8] A border separating coastal parts of the Chukchi Peninsula.

Figure 5. Dendrogram of the similarity of proportions of longitudinal subgroups in the local floras.

Various clusters are indicated with numbers and letters which are used in the text and in Table 2. Local floras are indicated by subprovince abbreviation and number. Similarity coefficient (2) values are represented in percentage scale.

Figure 6. Positions of local floras from the various clusters obtained through the analysis of the longitudinal structure (Fig. 5) in (A) the Yamal-Gydan and Taimyr sectors and in (B) the Chukotkan sector.

Clusters are indicated with the same numbers, letters and colors as in Fig. 5.

Figure 7. Locations of nine re-visited local floras and proportions of latitudinal subgroups among new species.

Location of the floras corresponds with the centers of larger and smaller circles. Circles with sector diagrams indicate sites where changes were reported and proportions of various latitudinal subgroups among new findings. Red small circles indicate sites where no changes were found. Local floras: 1, Yamu-Neru; 2, Ary-mas; 3, Saskylakh, 4, Tiksi Harbour; 5, Chokurdakh; 6, Polyarnui; 7, Ngaranato Lake; 8, Dikson; 9, Tareya.

See details on distribution of latitudinal subgroups in Table 1. 
Table 1. Description of phytogeographical elements (longitudinal and latitudinal groups and subgroups) in the Russian Arctic flora

\begin{tabular}{|c|c|c|c|}
\hline & Groups & Subgroups & Species range \\
\hline \multirow{16}{*}{ 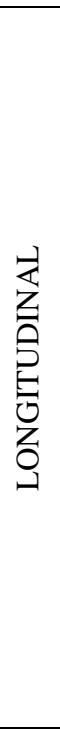 } & $\begin{array}{l}\text { I. Circum- } \\
\text { polar }\end{array}$ & $\begin{array}{l}\text { 1. Circumpolar } \\
\text { 2. Almost Circumpolar }\end{array}$ & $\begin{array}{l}\text { Extended ranges within Eurasia and North America } \\
\text { As Circumpolar, but absent in one of the sectors }\end{array}$ \\
\hline & & 3. Eurasian & Broad ranges from Fennoscandia to Chukotka \\
\hline & & 4. West Eurasian & Predominantly in the European Arctic, including species reaching Yamal-Gydan and Western Taimyr \\
\hline & II. Eura- & 5. Asian & From the Urals to the Kolyma River and even to Eastern Chukotka \\
\hline & sian & 6. East Asian & Eastwards from the Enisei, or the Lena Rivers to the Kolyma River, or even spreading in Chukotka \\
\hline & & 7. Middle Siberian & Only within Taimyr, the Putorana Plateau and the Anabar-Olenek sector \\
\hline & & 8. Chukotkan & Ranges eastward from the Kolyma River \\
\hline & III. Predo- & 9. Eurasian-West American & Pan- Eurasia and Alaska until the lower reaches of the Mackenzie River \\
\hline & minantly & 10. Asian-West American & From the Ural Mts to Chukotka and also to the lower reaches of the Mackenzie River in Alaska \\
\hline & Eurasian & $\begin{array}{l}\text { 11. East Asian-West American } \\
\text { 12. East American - Eurasian }\end{array}$ & $\begin{array}{l}\text { From the Enisei or the Lena Rivers to Chukotka and to the lower reaches of the Mackenzie River in Alaska } \\
\text { In tundra zone in the eastern North America and in Eurasia, but absent in Chukotka }\end{array}$ \\
\hline & IV. Predo- & 13. East Asian-American & From the Enisei or the Lena Rivers eastwards to Chukotka and in North America from Alaska to the Atlantic coast \\
\hline & minantly & 14. Chukotkan-American & Chukotka and northern North America \\
\hline & American & $\begin{array}{l}\text { 15. Chukotkan-American-West } \\
\text { Eurasian }\end{array}$ & Chukotka, northern North America and the western part of Eurasia up to western Taimyr \\
\hline & V.Ocea- & 16. Amphi-oceanic & On the northern coasts of both the Atlantic and the Pacific \\
\hline & nic & 17. Amphi-Pacific & Chukotka and Alaska until the lower reaches of the Mackenzie River \\
\hline & & 18. Amphi-Atlantic & Eastern North American - eastern Eurasian and Eastern American - European - West Siberian \\
\hline \multirow{7}{*}{ 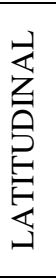 } & & 1. Arctic & Only within tundra zone \\
\hline & Arctic & 2. Metaarctic & In tundra zone and in adjacent subarctic mountains \\
\hline & Aнй & 3. Arctic-alpine & In tundra zone and in mountain tundra in adjacent and southern mountains \\
\hline & Hypo- & 4. Hypoarctic & Ranges within northern taiga and in hypoarctic tundra \\
\hline & arctic & 5. Hypoarctic-montane & Range within northern taiga and tundra, also the forest belt and mountain tundra of the southern mountains \\
\hline & Boreal & 6. Arctic-boreal & Wide ranges in both taiga and tundra zones, also in the steppe zone \\
\hline & & 7. Boreal & Ranges in taiga and steppe zones, limited ranges in tundra zone, including polyzonal and boreal-montane \\
\hline
\end{tabular}


Table 2. Percentage of longitudinal geographical subgroups in local floras (LF) in Yamal-Gydan, Taimyr and Chukotka.

\begin{tabular}{|c|c|c|c|c|c|c|c|c|c|}
\hline \multirow[t]{2}{*}{ Subgroups } & \multicolumn{9}{|c|}{$\begin{array}{l}\text { Mean percentage of longitudinal subgroups ( } \pm \text { standard error) in clusters of LF as shown on fig. } 5 \text { and } 6 . \\
\text { Number of LF in each cluster and their approximate location are given in brackets }\end{array}$} \\
\hline & $\begin{array}{l}\text { 1A } \\
\text { (15 LF, } \\
\text { south of } \\
\text { Yamal- } \\
\text { Gydan) }\end{array}$ & $\begin{array}{l}\text { 1Bc } \\
\text { (11 LF, } \\
\text { north of } \\
\text { Yamal- } \\
\text { Gydan) }\end{array}$ & $\begin{array}{c}\mathbf{1 B b} \\
\text { (12 LF, } \\
\text { northern } \\
\text { coast of } \\
\text { Taimyr) }\end{array}$ & $\begin{array}{c}\text { 1Ba } \\
\text { (14 LF, } \\
\text { southern } \\
\text { part of } \\
\text { Taimyr) }\end{array}$ & $\begin{array}{c}\text { 2A } \\
\text { (2 LF, } \\
\text { west of } \\
\text { Continental } \\
\text { Chukotka, } \\
\text { forest-tundra) }\end{array}$ & $\begin{array}{c}\text { 2B } \\
(18 \mathrm{LF} \text {, } \\
\text { east of the } \\
\text { Chukchi } \\
\text { Peninsula) }\end{array}$ & $\begin{array}{c}\text { 2C } \\
\text { (24 LF, } \\
\text { northern coast } \\
\text { of Chukotka } \\
\text { and Wrangel) }\end{array}$ & $\begin{array}{c}\text { 2Da } \\
\text { (20 LF, } \\
\text { Beringian } \\
\text { and } \\
\text { Southern } \\
\text { Chukotka) }\end{array}$ & $\begin{array}{c}\text { 2Db } \\
(20 \mathrm{LF}, \\
\text { most of } \\
\text { Continental } \\
\text { Chukotka) }\end{array}$ \\
\hline 1. Circumpolar* & $45.0 \pm 1.0$ & $59.6 \pm 2.6$ & $53.9 \pm 1.1$ & $45.4 \pm 0.8$ & $33.0 \pm 1.5$ & $33.4 \pm 0.5$ & $37.8 \pm 0.7$ & $32.1 \pm 0.3$ & $31.6 \pm 0.5$ \\
\hline 2. Almost circumpolar & $5.0 \pm 0.3$ & $3.4 \pm 0.5$ & $5.2 \pm 0.5$ & $7.4 \pm 0.3$ & $6.5 \pm 0.5$ & $5.6 \pm 0.2$ & $5.8 \pm 0.3$ & $7.2 \pm 0.2$ & $6.6 \pm 0.2$ \\
\hline 3. Eurasian & $11.4 \pm 0.5$ & $8.1 \pm 0.4$ & $4.6 \pm 0.4$ & $7.2 \pm 0.3$ & $8.4 \pm 1.5$ & $1.1 \pm 0.2$ & $2.2 \pm 0.3$ & $2.9 \pm 0.2$ & $2.3 \pm 0.1$ \\
\hline 4. West Eurasian & $8.6 \pm 0.6$ & $3.4 \pm 0.6$ & $0.5 \pm 0.2$ & $1.6 \pm 0.2$ & - & - & - & - & - \\
\hline 5. Asian & $3.8 \pm 0.4$ & $2.5 \pm 0.3$ & $5.7 \pm 0.4$ & $6.1 \pm 0.3$ & $4.4 \pm 0.5$ & $0.8 \pm 0.1$ & $2.8 \pm 0.1$ & $3.0 \pm 0.1$ & $1.9 \pm 0.1$ \\
\hline 6. East Asian & $0.4 \pm 0.2$ & $0.1 \pm 0.1$ & $1.3 \pm 0.3$ & $3.6 \pm 0.4$ & $11 \pm 1.0$ & $2.5 \pm 0.2$ & $5.8 \pm 0.4$ & $9.0 \pm 0.4$ & $5.3 \pm 0.4$ \\
\hline 7. Middle Siberian & $0.4 \pm 0.2$ & $0.3 \pm 0.2$ & $1.6 \pm 0.4$ & $3.0 \pm 0.4$ & - & - & - & - & - \\
\hline 8. Chukotkan & $\begin{array}{c}0.1-0.2 \\
-\end{array}$ & $\begin{array}{c}0.0-2 \\
-\end{array}$ & $0.1 \pm 0.1$ & & $2.4 \pm 0.5$ & $3.4 \pm 0.2$ & $5.0 \pm 0.4$ & $5.3 \pm 0.2$ & $4.9 \pm 0.4$ \\
\hline 9. Eurasian-west American & $10.4 \pm 0.3$ & $10.5 \pm 1.0$ & $8.8 \pm 0.4$ & $8.6 \pm 0.4$ & $9 \pm 0$ & $6.8 \pm 0.3$ & $7.3 \pm 0.2$ & $8.0 \pm 0.2$ & $7.1 \pm 0.2$ \\
\hline $\begin{array}{l}\text { 10. Asian- west American } \\
\text { 11. East Asian-West }\end{array}$ & $5.3 \pm 0.6$ & $6.5 \pm 0.7$ & $10.1 \pm 0.5$ & $9.7 \pm 0.4$ & $7.4 \pm 0.5$ & $7.0 \pm 0.3$ & $9.0 \pm 0.2$ & $7.7 \pm 0.2$ & $\begin{array}{l}7.7 \pm 0.2 \\
10.9 \pm 0.3\end{array}$ \\
\hline American & $0.2 \pm 0.1$ & $0.2 \pm 0.2$ & $2.3 \pm 0.5$ & $3.0 \pm 0.3$ & $7.4 \pm 0.5$ & $9.8 \pm 0.3$ & $8.6 \pm 0.3$ & $10.3 \pm 0.3$ & \\
\hline 12. East American-Eurasian & $2.8 \pm 0.2$ & $2.8 \pm 0.3$ & $3.4 \pm 0.2$ & $2.5 \pm 0.2$ & $0.5 \pm 0.5$ & $0.3 \pm 0.1$ & $0.9 \pm 0.1$ & $0.4 \pm 0.1$ & $0.4 \pm 0.1$ \\
\hline 13. East Asian-American & $0.1 \pm 0.1$ & $0.2 \pm 0.2$ & $1.3 \pm 0.2$ & $1.3 \pm 0.2$ & $4 \pm 0$ & $3.4 \pm 0.3$ & $3.1 \pm 0.2$ & $3.7 \pm 0.2$ & $3.4 \pm 0.1$ \\
\hline 14. Chukotkan-American & - & - & $0.1 \pm 0.1$ & - & $1 \pm 0$ & $4.7 \pm 0.3$ & $2.7 \pm 0.3$ & $1.5 \pm 0.2$ & $2.9 \pm 0.2$ \\
\hline $\begin{array}{l}\text { 15. Chukotkan-American - } \\
\text { West Eurasian }\end{array}$ & $2.6 \pm 0.2$ & $0.9 \pm 0.2$ & $0.7 \pm 0.2$ & $0.2 \pm 0.1$ & $1.5 \pm 0.5$ & $3.8 \pm 0.2$ & $1.9 \pm 0.1$ & $2.4 \pm 0.2$ & $2.8 \pm 0.1$ \\
\hline 16. Amphi-oceanic & $1.8 \pm 0.2$ & $0.2 \pm 0.1$ & $\begin{array}{c}0.1-2 \\
-\end{array}$ & $\begin{array}{c}0.2 \pm 0.1 \\
-\end{array}$ & $\begin{array}{c}1.0 \pm 0.0 \\
-\end{array}$ & $2.1 \pm 0.2$ & $0.1 \pm 0.1$ & $0.2 \pm 0.1$ & $0.8 \pm 0.1$ \\
\hline 17. Amphi-Pacific & - & - & $0.3 \pm 0.3$ & - & $3.5 \pm 0.5$ & $15.3 \pm 0.4$ & $7.0 \pm 0.3$ & $6.7 \pm 0.3$ & $12.2 \pm 0.4$ \\
\hline 18. Amphi-Atlantic & $2.3 \pm 0.2$ & $1.5 \pm 0.2$ & $0.3 \pm 0.1$ & $0.4 \pm 0.1$ & - & - & - & - & - \\
\hline
\end{tabular}

Note: * For explanation of groups, see Table 1. 
Table 3. Summary of re-inventory of nine local floras in the Russian Arctic.

\begin{tabular}{|c|c|c|c|c|c|}
\hline $\begin{array}{l}\text { Local flora } \\
\text { (number as in Fig.7, } \\
\text { name, region) }\end{array}$ & $\begin{array}{l}\text { Sub- } \\
\text { zone }\end{array}$ & $\begin{array}{l}\text { First survey: } \\
\text { number of species; } \\
\text { year; reference }\end{array}$ & $\begin{array}{l}\text { Re-inventory: } \\
\text { number of species, } \\
\text { year, reference }\end{array}$ & Changes & Trends \\
\hline $\begin{array}{l}\text { 1.'Yamu-Neru', } \\
\text { Eastern Taymyr }\end{array}$ & $\mathrm{D}$ & $\begin{array}{l}170 \text { species; } \\
\text { 1928; } \\
\text { Tolmatchev 1932a,b }\end{array}$ & $\begin{array}{l}203 \text { species; } \\
\text { 1999; Pospelova, } \\
\text { Pospelov, 2001 }\end{array}$ & $\begin{array}{l}\text { new } \\
\text { species }\end{array}$ & $\begin{array}{l}\text { No change in proportion of latitudinal subgroups. Occurrence } \\
\text { decreased from sparse to rare in } 12 \text { Arctic, but increased from } \\
\text { rare to sparse in } 20 \text { Hypoarctic species. }\end{array}$ \\
\hline $\begin{array}{l}\text { 2. 'Ary-Mas', } \\
\text { EasternTaimyr }\end{array}$ & $\mathrm{E}$ & $\begin{array}{l}258 \text { species; } \\
\text { 1972; } \\
\text { Vargina 1978; }\end{array}$ & $\begin{array}{l}280 \text { species; } \\
\text { 2002; 2012; Pospelov, } \\
\text { Pospelova } 2005\end{array}$ & $\begin{array}{l}\text { new } \\
\text { species }\end{array}$ & $\begin{array}{l}\text { Among new species, Boreal group is prevailing: } 30 \% \text { vs. } 10 \% \text { in } \\
\text { the old checklist, however, in the total checklist only 3\% } \\
\text { increase }\end{array}$ \\
\hline $\begin{array}{l}\text { 3.'Saskylakh' on the } \\
\text { Anabar River, Anabar- } \\
\text { Olenek }\end{array}$ & $\mathrm{F}$ & $\begin{array}{l}222 \text { species; } \\
1978 ; \\
\text { Andreev et al } 1980\end{array}$ & $\begin{array}{l}304 \text { species; } \\
\text { 2011-2012; Koroleva } \\
\text { and Gogoleva (unpubl) }\end{array}$ & $\begin{array}{l}\text { new } \\
\text { species }\end{array}$ & $\begin{array}{l}7 \% \text { increase in proportions of Boreal and Hypoarctic groups in } \\
\text { the new checklist compare to the old. } 25 \% \text { of new species are } \\
\text { Boreal species. }\end{array}$ \\
\hline $\begin{array}{l}\text { 4.`Tiksi Harbour’, east } \\
\text { of the Lena River, } \\
\text { Kharaulakh }\end{array}$ & $\mathrm{D}$ & $\begin{array}{l}220 \text { species*; } \\
\text { 1950-1954; } \\
\text { Tikhomirov et al. } 1966\end{array}$ & $\begin{array}{l}227 \text { species; } \\
\text { 2004; } \\
\text { Sekretareva, Sytin } 2006\end{array}$ & $\begin{array}{l}\text { new and } \\
\text { not found } \\
\text { species }\end{array}$ & $\begin{array}{l}50 \% \text { of new species belong to Boreal group; totally } 7 \% \text { increase } \\
\text { in Boreal and Hypoarctic groups compare to old checklist, not } \\
\text { found snowbed species }\end{array}$ \\
\hline $\begin{array}{l}\text { 5. 'Chokurdakh', on } \\
\text { the Indigirka River, } \\
\text { Yana-Kolyma }\end{array}$ & $\mathrm{E}$ & $\begin{array}{l}167 \text { species } \\
1969 \text { and } 1981 ; \\
\text { Boch \& Tsaryova 1974; } \\
\text { Egorova } 1991\end{array}$ & $\begin{array}{l}225 \text { species; } \\
2013-2014 ; \\
\text { Koroleva \& Gogoleva } \\
\text { (unpubl.) }\end{array}$ & $\begin{array}{l}\text { new } \\
\text { species }\end{array}$ & $\begin{array}{l}7 \% \text { increase in proportions of Boreal and Hypoarctic groups in } \\
\text { new compare to the old checklist, but } 22 \% \text { Boreal subgroup } \\
\text { among new species vs. } 9 \% \text { in complete old checklist }\end{array}$ \\
\hline $\begin{array}{l}\text { 6.'Polyarnui' on the } \\
\text { Indigirka River, Yana- } \\
\text { Kolyma }\end{array}$ & $\mathrm{D}$ & $\begin{array}{l}101 \text { species } \\
\text { 1969; } \\
\text { Boch \&Tsaryova } 1974\end{array}$ & $\begin{array}{l}150 \text { species } \\
\text { 2013-2014; Koroleva \& } \\
\text { Gogoleva (unpubl.) }\end{array}$ & $\begin{array}{l}\text { new } \\
\text { species }\end{array}$ & $\begin{array}{l}\text { No change in proportions of subgroups, } 25 \% \text { of new species } \\
\text { belong to Metaarctic subgroup, as in the old checklist; } 3 \% \\
\text { increased proportion of Hypoarctic group in the new checklist }\end{array}$ \\
\hline $\begin{array}{l}\text { 7. 'Ngaranato Lake', } \\
\text { Central Yamal }\end{array}$ & $\mathrm{D}$ & $\begin{array}{l}155 \text { species; } \\
\text { 1991-1993, Rebristaya } \\
\text { \& Khitun } 1998\end{array}$ & $\begin{array}{l}155 \text { species; } \\
2012 ; \\
\text { Khitun (unpubl.) }\end{array}$ & no & no \\
\hline $\begin{array}{l}\text { 8.'Dikson', polar } \\
\text { station, Western } \\
\text { Taimyr }\end{array}$ & B & $\begin{array}{l}\text { 140 species; } \\
\text { 1980; Matveeva, } \\
\text { Zanokha } 1997\end{array}$ & $\begin{array}{l}140 \text { species; } \\
\text { 2012; Matveeva \& } \\
\text { Zanokha } 2013\end{array}$ & $\begin{array}{l}\text { no new } \\
\text { species }\end{array}$ & $\begin{array}{l}\text { One-grade decrease in frequency of occurrence of several Arctic } \\
\text { herbs }\end{array}$ \\
\hline $\begin{array}{l}\text { 9.'Tareya', on the } \\
\text { Pyasina River, } \\
\text { Western Taimyr }\end{array}$ & $\mathrm{D}$ & $\begin{array}{l}219 \text { species*; } \\
\text { 1965-73; Polozova \& } \\
\text { Tikhomirov 1971; } \\
\text { Matveeva 1978; }\end{array}$ & $\begin{array}{l}193 \text { species; } \\
2010 ; \\
\text { Matveeva et al. } 2015\end{array}$ & $\begin{array}{l}\text { uncer- } \\
\text { tain** }\end{array}$ & $\begin{array}{l}\text { Some species not found due to shorter visit, however } 75 \% \text { of } 10 \\
\text { new species belong to Hypoarctic and Arctic-Boreal subgroups. } \\
\text { One-grade decrease in frequency and abundance of several } \\
\text { Arctic herbs }\end{array}$ \\
\hline
\end{tabular}

* Within the area which was re-visited

** Authors of re-inventory concluded that there were no changes; however their data can be interpreted in the other way 
Table 4. Number of new species in various latitudinal subgroups found in re-inventory of nine local floras (with examples of species in each subgroup)

\begin{tabular}{|c|c|c|c|}
\hline $\begin{array}{l}\text { Local } \\
\text { flora }\end{array}$ & $\begin{array}{l}\text { Arctic (A) + Metaarctic (MA) +Arctic-alpine } \\
(\text { AA) }\end{array}$ & $\begin{array}{l}\text { Hypoarctic (HA) + Hypoarctic- } \\
\text { montane(HAM) }\end{array}$ & Arctic-Boreal (AB) + Boreal (B) \\
\hline $\begin{array}{l}1 . * \\
\text { 'Yamu- } \\
\text { Neru' }\end{array}$ & $\begin{array}{l}\text { 5 A (Dupontia psilosantha, Pedicularis villosa); } \\
\text { 4MA (Carex maritima, Potentilla uniflora); } \\
8 \text { AA (Festuca auriculata, Potentilla rubella, } \\
\text { Artemisia furcata, Pedicularis amoena). }\end{array}$ & $\begin{array}{l}3 \text { HA (Hierochloe pauciflora, Carex supina } \\
\text { subsp. spaniocarpa, Taraxacum lateritium); } \\
8 \text { HAM (Juncus castaneus, Astragalus } \\
\text { norvegicus, Ranunculus trichophyllum). }\end{array}$ & $\begin{array}{l}5 \mathrm{AB} \text { (Eriophorum vaginatum, Carex chordorrhiza, } \\
\text { Comarum palustre, Ranunculus lapponicus, Hippuris } \\
\text { vulgaris); } \\
0 \mathrm{~B} .\end{array}$ \\
\hline $\begin{array}{l}\text { 2. 'Ary- } \\
\text { Mas' }\end{array}$ & $\begin{array}{l}2 \text { A (Pedicularis villosa, Oxytropis adamsiana); } \\
3 \text { MA (Deschampsia obensis, Stellaria } \\
\text { edwardsii); } \\
3 \text { AA (Carex glacialis, Carex krausei) }\end{array}$ & $\begin{array}{l}\text { 4 HA (Carex supina subsp. spaniocarpa, } \\
\text { Myriophyllum sibiricum, Puccinellia sibirica); } \\
1 \text { HAM (Astragalus frigidus) }\end{array}$ & $\begin{array}{l}1 \mathrm{AB} \text { (Equisetum palustre); } \\
7 \mathrm{~B} \text { (Chamaenerion angustifolium, Eleocharis } \\
\text { acicularis, Castilleja rubra, Poa sibirica, Salix } \\
\text { dasyclados auct.) }\end{array}$ \\
\hline $\begin{array}{l}3 . \\
\text { 'Sasky- } \\
\text { lakh' }\end{array}$ & $\begin{array}{l}6 \text { A (Dupontia psilosantha, Papaver pulvinatum } \\
\text { subsp. interius, Artemisia arctisibirica); } \\
11 \text { MA (Saxifraga cespitosa, Sagina intermedia, } \\
\text { Silene paucifolia, Oxytropis mertensiana); } \\
6 \text { AA (Carex lachenalii, Oxyria digyna) }\end{array}$ & $\begin{array}{l}10 \text { HA (Dianthus repens, Poa sublanata, } \\
\text { Rumex sibiricus); } \\
14 \text { HAM (Carex rotundata, Agrostis kudoi, } \\
\text { Viola biflora, Calamagrostis lapponica, } \\
\text { Elymus alaskanus subsp. borealis) }\end{array}$ & $\begin{array}{l}10 \text { AB (Equisetum scirpoides, Sparganium } \\
\text { hyperboreum, Angelica decurrens); } \\
25 \mathrm{~B}(\text { Androsace filiformis, Castilleja rubra, } \\
\left.\text { Chamaenerion angustifolium, Hordeum jubatum }{ }^{\mathrm{a}}\right), \\
\text { Poa palustris, Corallorhiza trifida, Gentiana plebeja) }\end{array}$ \\
\hline $\begin{array}{l}4 . \\
\text { 'Tiksi' }\end{array}$ & $\begin{array}{l}2 \text { A(Pedicularis villosa, Puccinellia borealis); } \\
1 \text { MA (Taraxacum korjakorum); } \\
1 \text { AA (Armeria scabra) }\end{array}$ & $\begin{array}{l}3 \text { HA (Castilleja caudata, Draba sibirica } \\
\text { subsp. arctica, Salix boganidensis); } \\
0 \text { HAM }\end{array}$ & $\begin{array}{l}2 \mathrm{AB} \text { (Ribes triste, Stellaria peduncularis); } \\
4 \mathrm{~B} \text { (Alopecurus arundinaceus }{ }^{\mathrm{a}} \text {, Hordeum } \\
\left.\text { brevisubulatum }^{a} \text {, Chamaenerion angustifolium }\right)\end{array}$ \\
\hline $\begin{array}{l}5 . \\
\text { 'Choku- } \\
\text { rdakh' }\end{array}$ & $\begin{array}{l}\text { 4 A (Cochlearia arctica subsp. arctica); } \\
7 \text { MA (Pedicularis hirsuta, Taraxacum } \\
\text { korjakorum, Deschampsia borealis, } \\
\text { Chrysosplenium tetrandrum); } \\
5 \text { AA (Salix reticulata, Pedicularis amoena) }\end{array}$ & $\begin{array}{l}\text { 14 HA (Carex lugens, Oxytropis leucantha } \\
\text { subsp. subarctica, Polygonum humifusum, } \\
\text { Vicia macrantha }{ }^{\mathrm{a}} \text {, Arnica iljinii); } \\
8 \text { HAM (Tofieldia pusilla, Lysiella oligantha, } \\
\text { Chamaenerion latifolium) }\end{array}$ & 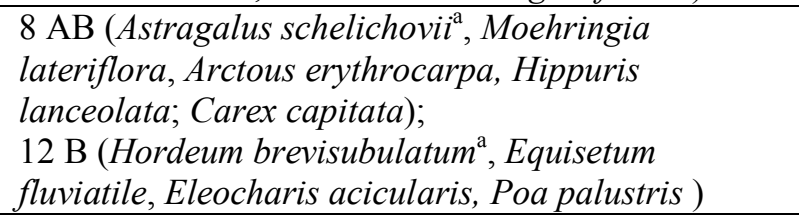 \\
\hline $\begin{array}{l}6 . \\
\text { 'Polyar- } \\
\text { nui' }\end{array}$ & $\begin{array}{l}\text { 6 A (Puccinellia borealis subsp. borealis), } \\
13 \text { MA (Salix reptans, Ranunculus affinis, } \\
\text { Pleuropogon sabinii, Trisetum spicatum, } \\
\text { Festuca hyperborea, Juncus arcticus); } \\
7 \text { AA (Eutrema edwardsii) }\end{array}$ & $\begin{array}{l}12 \text { HA (Salix boganidensis, Taraxacum } \\
\text { lateritium, T. macilentum, Saxifraga radiata, } \\
\text { Arctophila fulva, Pedicularis pennellii, Draba } \\
\text { juvenilis, Ranunculus hyperboreus); } \\
4 \text { HAM (Tanacetum bipinnatum) }\end{array}$ & $\begin{array}{l}9 \mathrm{AB} \text { (Ranunculus lapponicus, Sparganium } \\
\text { hyperboreum, Hippuris lanceolata, Arctous } \\
\text { erythrocarpa, } \\
3 \mathrm{~B} \text { (Equisetum fluviatile, Trisetum molle) }\end{array}$ \\
\hline $\begin{array}{l}\text { 9. 'Ta- } \\
\text { reya' }\end{array}$ & $\begin{array}{l}0 \text { A; } \\
1 \text { MA (Taraxacum sibiricum); } \\
1 \text { AA (Poa alpina) }\end{array}$ & $\begin{array}{l}4 \text { HA (Elymus fibrosus subsp. subfibrosus, E. } \\
\text { kronokensis, Rumex acetosa subsp. } \\
\text { lapponicus); } \\
1 \text { HAM (Taraxacum bicorne) }\end{array}$ & $\begin{array}{l}4 \mathrm{AB}(\text { Cerastium arvense, Veratrum lobelianum, Poa } \\
\text { pratensis, Potentilla arenosa); } \\
0 \mathrm{~B} .\end{array}$ \\
\hline
\end{tabular}

*For location of local floras see fig.7. Floras are indicated with the same numbers as on the map. Those locations where there were no new findings are not included in the table; Hordeum jubatum ${ }^{\text {a }}$ - species most probably was dispersed by humans, anthropochore. 


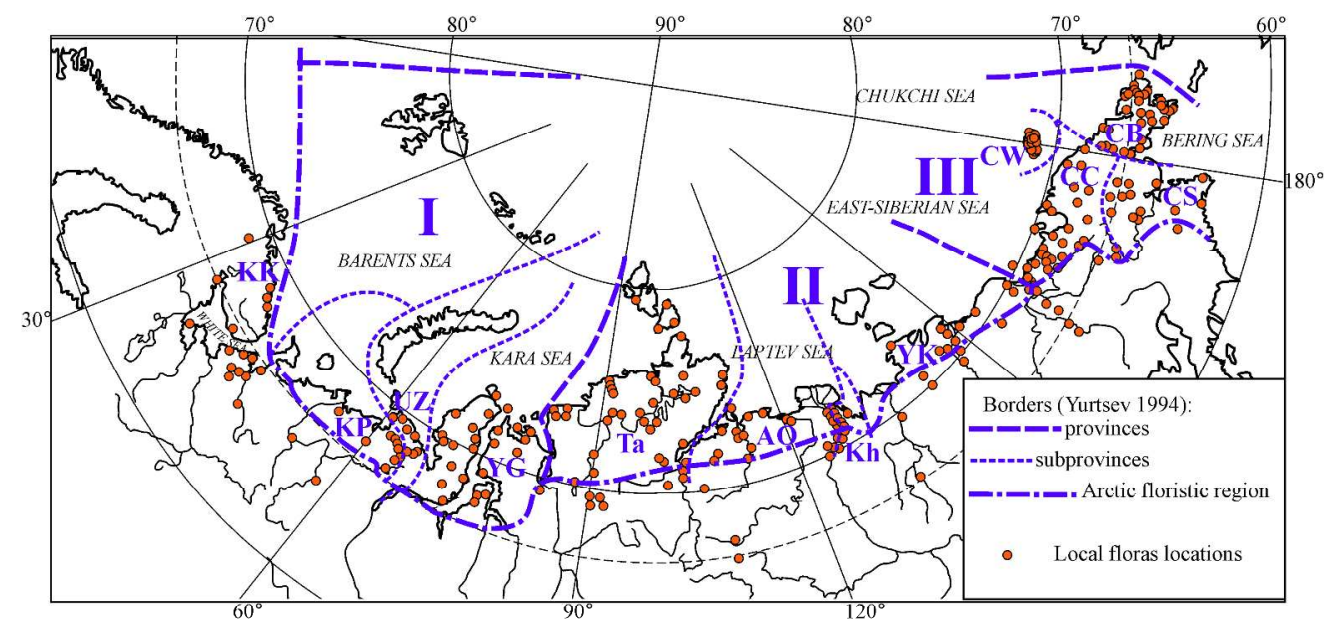

Figure 1. The Russian Arctic and Subarctic local floras network. + Provinces and subprovinces (Yurtsev 1994): I, European-West Siberian Province, including Kanin-Pechora (KP), Ural-Novaya Zemlya (UZ) and Yamal-Gydan (YG) subprovinces; II, East Siberian Province, including Taimyr (Ta), Anabar-Olenek (AO), Kharaulakh (Kh) and Yana-Kolyma (YK); III, Chukotka province, including Continental Chukotka (CC), Wrangel Island (CW), Southern Chukotka (CS), Beringian Chukotka (CB). Kola-Karelian (KK) subprovince was not included by Yurtsev into the Arctic floristic region.

$$
296 \times 161 \mathrm{~mm}(300 \times 300 \mathrm{DPI})
$$




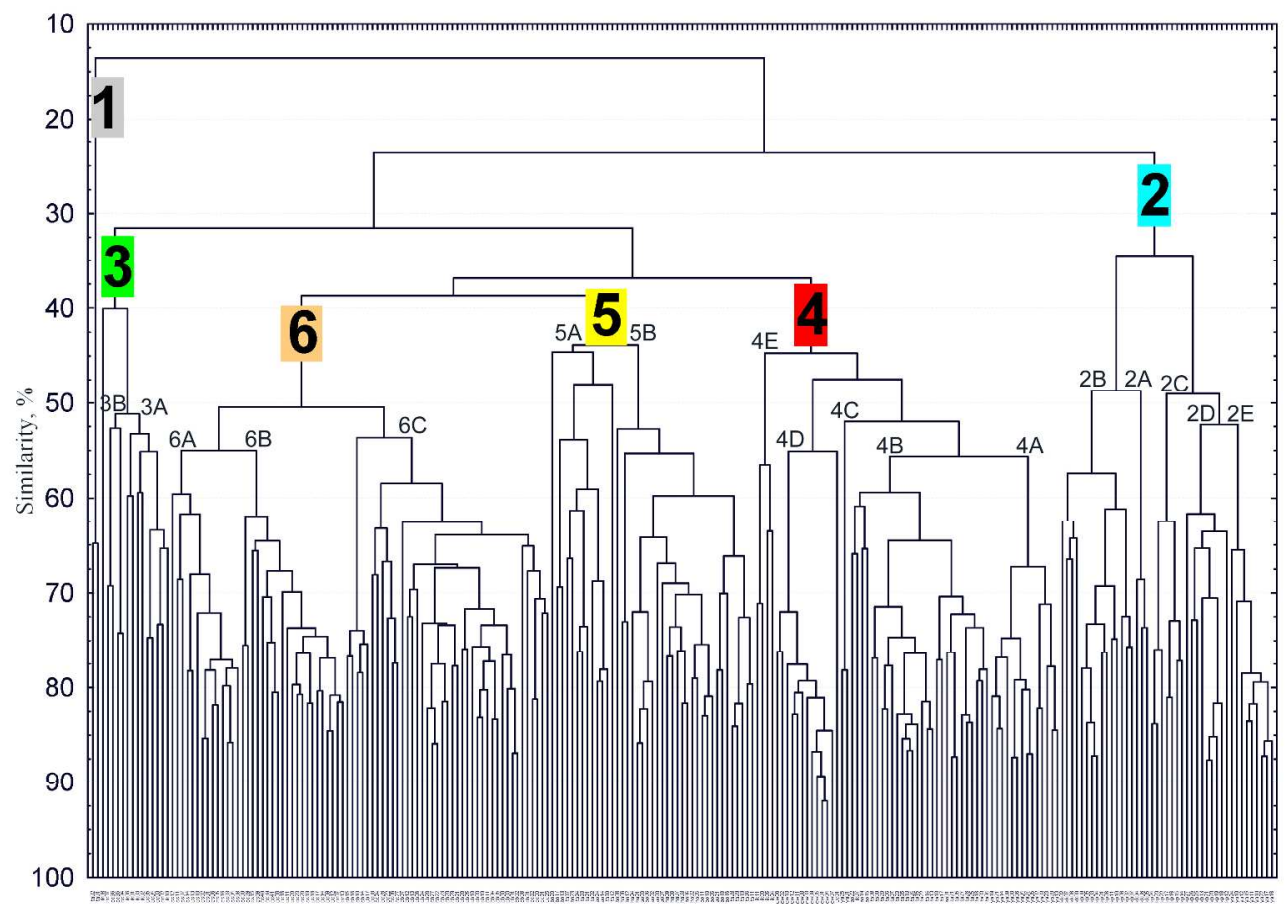

Figure 2. Dendrogram of pair-wise species composition similarity of 240 local floras in the Russian Arctic. The various clusters are indicated by numbers, letters and color. Each local flora name is coded by the abbreviation of subprovince name (as in Fig.1, but "ya" for the Yamal-Gydan subprovince and "ha "for the Kharaulakh subprovince) and the number. In the database all local floras are numbered in serial order separately in each subprovince. Similarity coefficient (1) values are represented in percentage scale. 


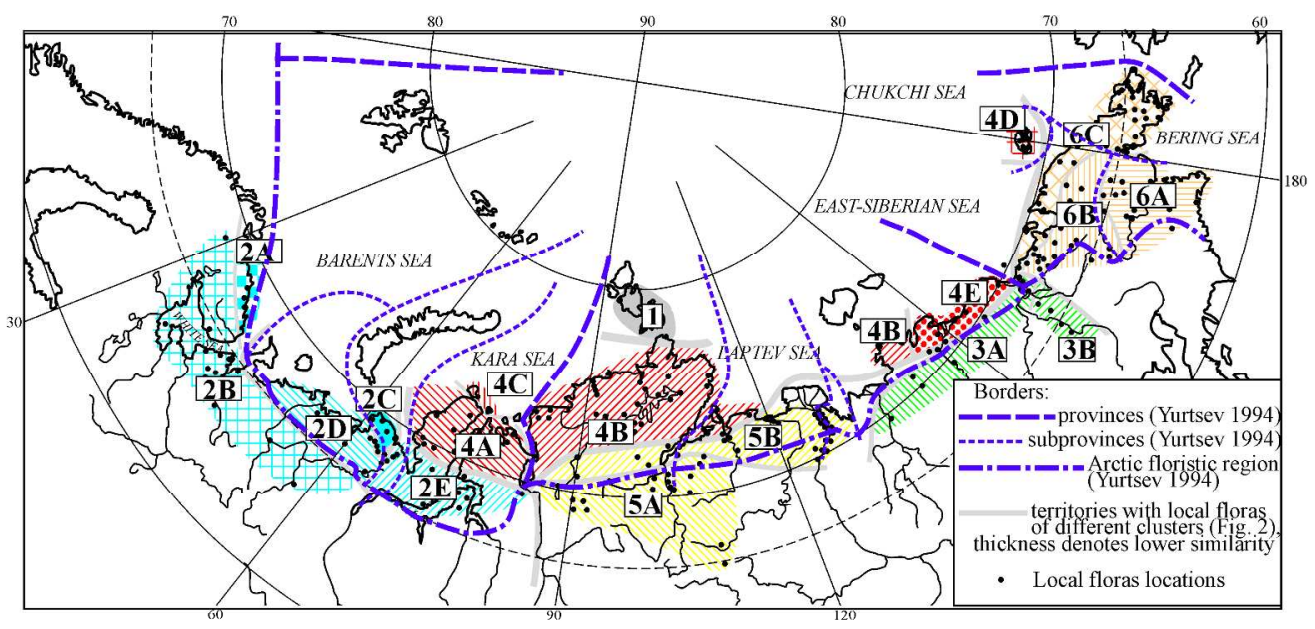

Figure 3. Differentiation of the Russian Arctic based on species composition similarity in local floras.!! + ! + The various clusters obtained in the dendrogram (Fig. 2) are shown by the same color and number on the map; sub-clusters are showed by different shades.! +

$290 \times 160 \mathrm{~mm}(300 \times 300 \mathrm{DPI})$ 


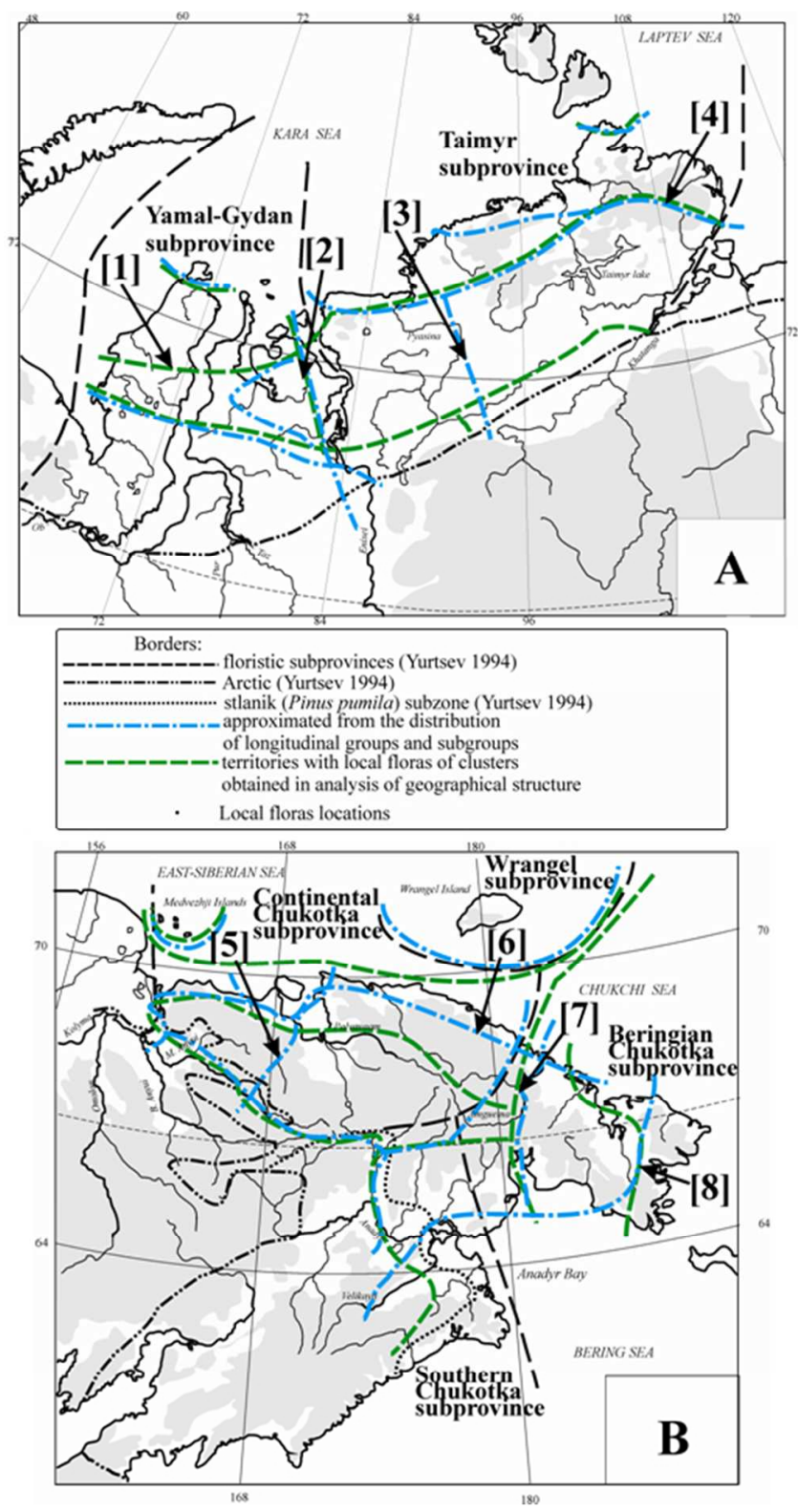

Figure 4. Floristic boundaries obtained through the analyses of the distribution of the longitudinal subgroups and similarity of longitudinal structure of local floras in (A) the Yamal-Gydan and Taimyr sectors and in (B) the Chukotkan sector. Arrows indicate some of the boundaries obtained in the analyses: [1] A boundary between northern and southern parts of Yamal, Gydan and Taimyr, roughly reflecting the border between

the Arctic proper and the Hypoarctic (i.e., between subzones $C$ and $D$ ), the borders below it roughly correspond to the border between the subzones $D$ and $E$; [2] A border separating eastern part of Gydan from the rest of the Yamal-Gydan subprovince; [3] A border along the Pyasina River separating Western and Eastern Taimyr; [4] A boundary north of the Taimyr Lake; [5] A border between western and central parts of Continental Chukotka and Beringian Chukotka; [6] A border, separating the northern coast of Continental Chukotka; [7] Borders indicating Amguema area; [8] A border separating coastal parts of the Chukchi Peninsula. 


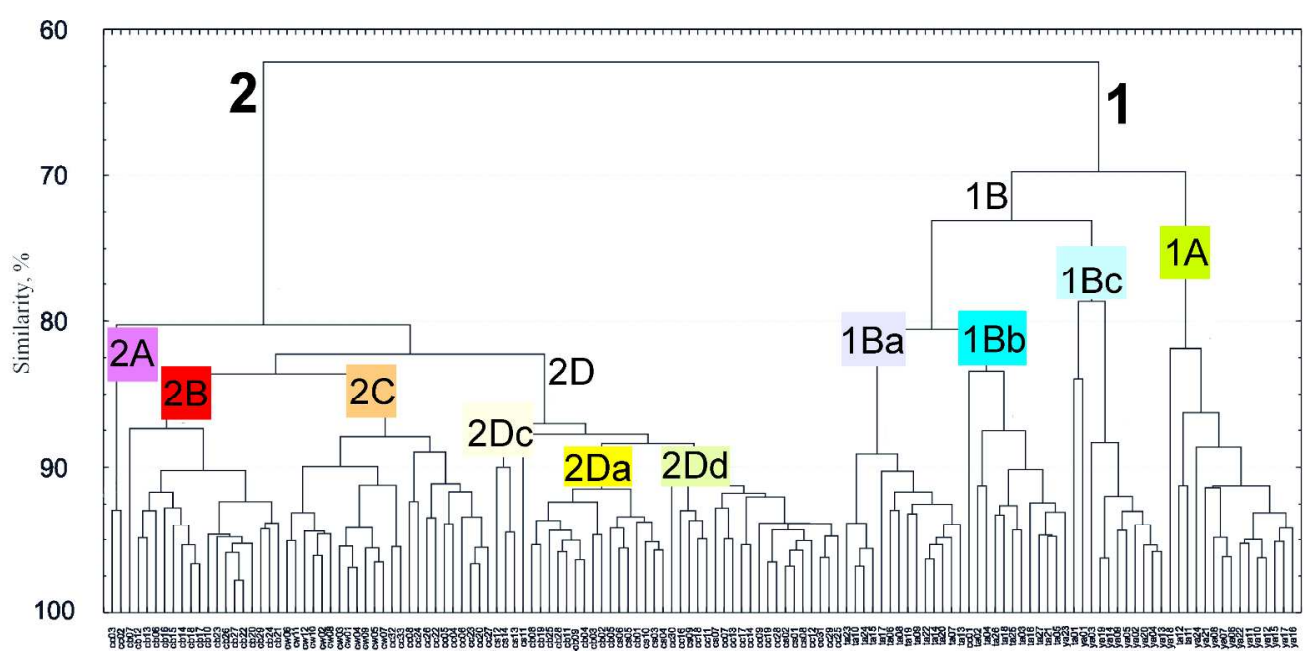

Figure 5. Dendrogram of the similarity of proportions of longitudinal subgroups in the local floras.

Various clusters are indicated with numbers and letters which are used in the text and in Table 2. Local floras are indicated by subprovince abbreviation and number. Similarity coefficient (2) values are represented in percentage scale.

$299 \times 144 \mathrm{~mm}(299 \times 299 \mathrm{DPI})$ 

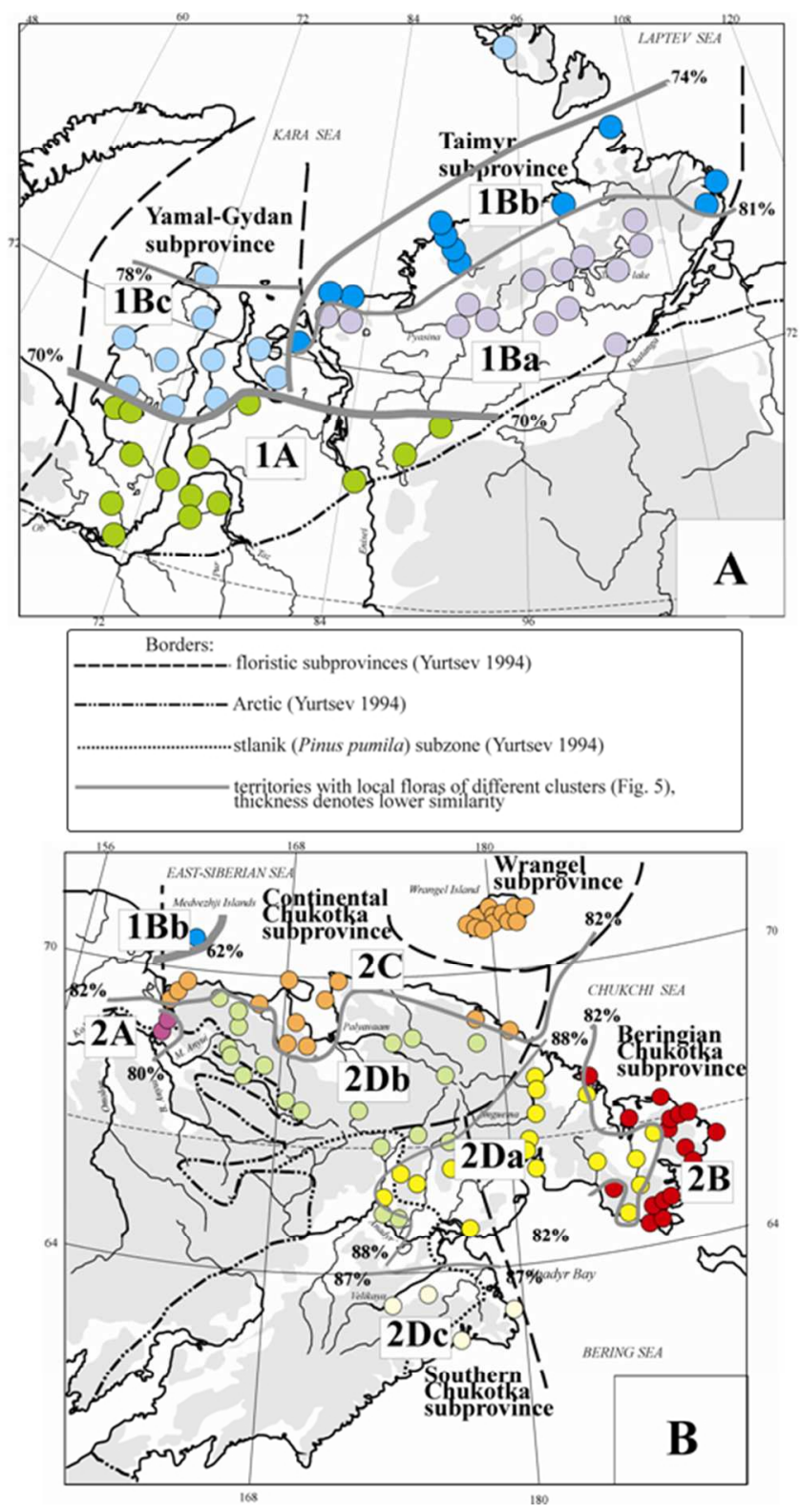

Figure 6. Positions of local floras from various clusters obtained through the analysis of the longitudinal structure (Fig. 5) in (A) the Yamal-Gydan and Taimyr sectors and in (B) the Chukotkan sector. Local floras from the various clusters are indicated with the same numbers, letters and colors as in Fig. 5. 


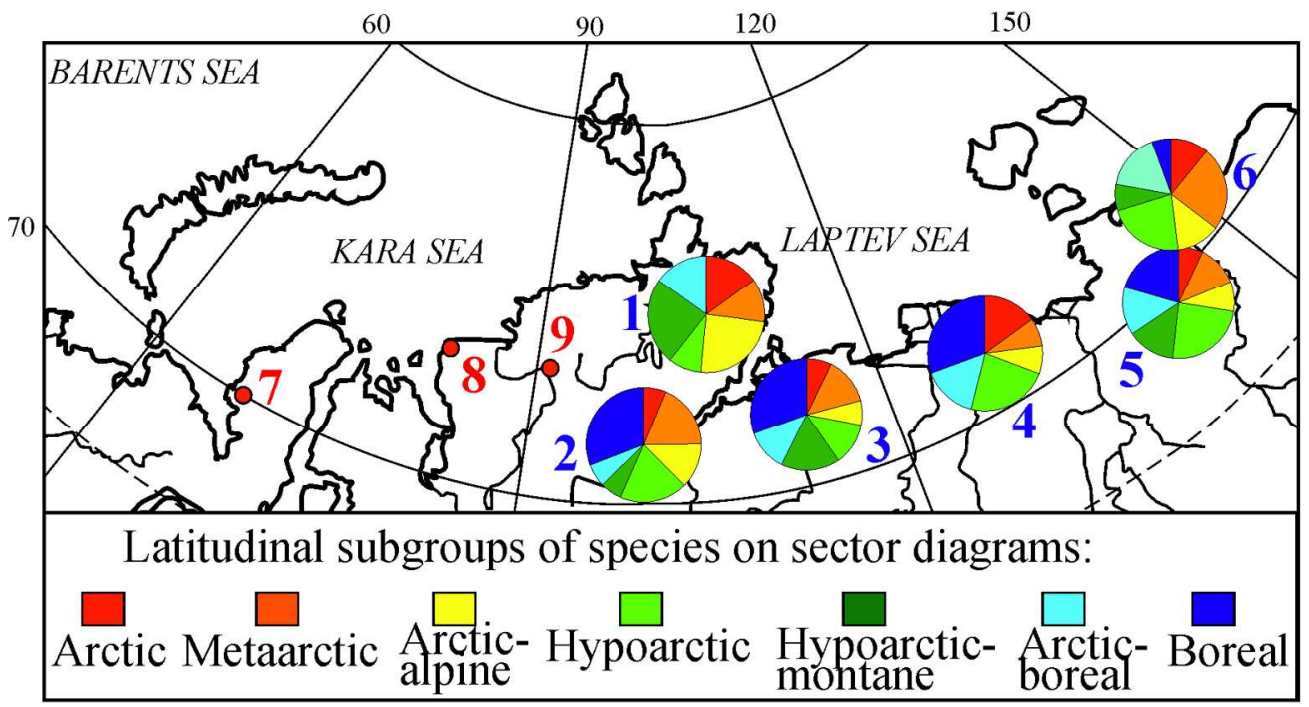

Figure 7. Locations of nine re-visited local floras and proportions of latitudinal subgroups among new species.

Location of the floras corresponds with the centers of larger and smaller circles. Circles with sector diagrams indicate sites where changes were reported and proportions of various latitudinal subgroups among new findings. Red small circles indicate sites where no changes were found. Local floras: 1, Yamu-Neru; 2, Arymas; 3, Saskylakh, 4, Tiksi Harbour; 5, Chokurdakh; 6, Polyarnui; 7, Ngaranato Lake; 8, Dikson; 9, Tareya. See details on distribution of latitudinal subgroups in Table 1.

$159 \times 85 \mathrm{~mm}(299 \times 299$ DPI $)$ 